\title{
Review:
}

\section{Various Adsorbents for Removal of Rhodamine B Dye: A Review}

\author{
Zainab Mohammad Saigl \\ Department of Chemistry, Faculty of Science, King Abdulaziz University, P.O. Box 80203, Jeddah 21589, Saudi Arabia
}

\section{* Corresponding author:}

tel: +966-12-6952000 ext. 26546

email:zsaigl@kau.edu.sa

Received: January 5, 2021

Accepted: May 10, 2021

DOI: $10.22146 / \mathrm{ijc} .62863$

\begin{abstract}
Lately, there has been an increase in dye manufacturing, resulting in increased environmental pollution. Recent studies show a wide availability of usage adsorbents, including banana peels, potatoes, algae, etc. Food and Drug Administration prohibited the use of Rhodamine $B(R h B)$ for its toxicity and harmful effects. Therefore, this study presents a wide range of non-conventional low-cost alternative adsorbents to remove $R h B$ dye from wastewater. It has been observed that the mechanism of the dye adsorption is focused on kinetics, isotherm, and thermodynamics models, which depend on the chemical nature of the materials and various physicochemical experimental conditions such as solution $\mathrm{pH}$, initial dye concentration, adsorbent dosage, and temperature of the system. The kinetic data of adsorption of $R h B$ dye usually follow the pseudo-first-order and pseudo-second-order kinetic models. Several studies revealed that Langmuir and Freundlich adsorption isotherm models are frequently used to evaluate the adsorption capacity of the adsorbents. Furthermore, thermodynamic examination showed that RhB adsorption was endothermic and unconstrained in nature. Thus, both photocatalytic degradation and adsorption methods offer good potential to remove RhB dye from industrial effluents. The work is in progress to evaluate the possibility of using other modified waste biomass for industrial pollution control.
\end{abstract}

Keywords: Rhodamine B dye; pseudo-second-order; thermodynamic; isotherm; agricultural wastes

\section{- INTRODUCTION}

Generally, water can be utilized as an excellent solvent, metabolite, and living environment. Unfortunately, due to the high technology required for industrial societies, several environmental problems appeared and negatively impacted the atmosphere. Over time, population growth, rapid industrialization, and urbanization represent big challenges, particularly the water resources in developing countries contaminated by organic and inorganic compounds such as chiral pollutants and heavy metals [1]. Thus, there are many research articles interested in this global problem [2-3]. As a result, water pollution by new emerging pollutants is becoming a subject of global anxiety, with hazardous environmental consequences [4].

Rhodamine $\mathrm{B}(\mathrm{RhB})$ dye is a synthetic dye widely used as a coloring in textiles and food products [5-7]. It is a bright red organic fluorescent pigment used as a coloring agent in various industries such as textiles, paper, paint, etc. Its high solubility in water and its lowcost nature makes it a commonly used pigment in various industries. Colors are characterized by complex chemical structures; subsequently, they are nonbiodegradable [8]. RhB dye, likes other dyes, stable to light, heat, oxidation, and is not biologically degradable [9]. Some studies suggest that $\mathrm{RhB}$ dye is considered as carcinogenic and mutagenic origin in animals and humans. It causes biological issues such as skin, respiratory inflammation, hemolysis, degenerative changes in the liver, and kidneys, etc. [5-6,10-11]. It is known as water tracer fluorescent as it is used as a tracker inside the water to evaluate the flow rate and direction of the water flow $[9,12]$.

This dye belongs to the xanthine family and is commonly used in the biological, analytical, and optical 
Table 1. General properties of Rhodamine B

\begin{tabular}{ll}
\hline Common name & Rhodamine B \\
\hline Chemical name & {$[$ 9-(2-carboxyphenyl)-6-diethylamino-3-xanthenylidene]-diethylammonium chloride } \\
\hline Chemical formula & $\mathrm{C}_{28} \mathrm{H}_{31} \mathrm{ClN}_{2} \mathrm{O}_{3}$ \\
\hline Molecular weight & $479.017 \mathrm{~g} / \mathrm{mol}$ \\
\hline Adsorption maximum & $545 \mathrm{~nm}$ \\
\hline Class & Triphenylmethane \\
\hline Appearance & Basic Violet 10; Brilliant Pink B
\end{tabular}

sciences [13]. Among its uses is that it is frequently used in the manufacture of paper, textile and leather dyeing, and fluorescent cell dyeing, and it is also found in wastewater [14-15]. Expanding release of a significant overabundance of dyes by color fabricating and material business leads to extreme environmental issues. RhB dye is broadly utilized for coloring, and their release in water bodies give antagonistic impacts on human and creature [16]. Now the rapid growth of industrialization and unplanned urbanization is causing severe environmental problems, especially for groundwater containing $\mathrm{RhB}$ stains, which is one of them. As a result, many studies and research conducted by scientists have reached the adsorption of $\mathrm{RhB}$ in many fields [17-18]. Therefore, the utilize of RhB dye as a colorant in foodstuffs was denied. In general, synthetic dyes are used to manufacture various types of paper, textiles, tanning leather, plastics, food processing, and rubber. Subsequently, when it is discharged into water, it is considered a dangerous source of contamination due to its intractable nature [19]. However, many merchants continue to utilize $\mathrm{RhB}$ as a food additive, imperiling the prosperity of clients. In this way, the advancement of a simple method for the assurance of $\mathrm{RhB}$ in numerous samples is fundamental [20].

Metal ions are the most toxic pollutants in the environment, non-biodegradable and highly toxic leading to carcinogenesis [21]. Removal of organic and inorganic pollutants from aqueous solutions mainly includes chemical, biological, and physical approaches. Various methods, including chemical precipitation, ion exchange, membrane separation, and adsorption, can handle these contaminants. While chemical precipitation is the most common technique, it does not appear to meet the requirements of the strict effluent standard. Therefore, adsorption is favored for the removal of pollutants from all different water treatment systems. It has many advantages over other separation methods, including high solid-phase stability and reusability, ease of separation, reduced costs due to low reagent use, and no need for toxic organic solvents [1]. Therefore, great attention has been oriented towards using various adsorbents such as nanoparticles, carbon nanotubes, graphene, and composite nanomaterials to separate organic and inorganic pollutants [4,22-25]. Moreover, the removal method using biomass has been increased because they are simple, eco-friendly, and cheap [10]. The residual biomass was turned into adsorbent materials after chemical activation with acids or chemical reagents, allowing the development of a large pore in the activated materials [26].

The current review shows the progress in the adsorption process using different adsorbents for removal of $\mathrm{RhB}$ dye to overcome the limitations that result from other techniques due to their complications. This would give the readers a broad insight into several possible modifications of adsorbents used for the 
effective separation of RhB dye. In addition, kinetic data, thermodynamic examination, and isotherm models of adsorption of $\mathrm{RhB}$ dye are frequently used to evaluate the adsorption capacity of the adsorbents. Thus, the present study aimed to determine the optimum conditions for removing $\mathrm{RhB}$ from an aqueous solution.

\section{Current Treatment Technology for Color Removal of Dyes}

As a type of xanthene color, $\mathrm{RhB}$ is produced by phenols and phthalic anhydride, and it is widely used in materials [27]. Extracting the dye from waste clothing is a great inspiration for most researchers worldwide [28]. These techniques include electrostatic deposition, coagulation, air stripping, membrane filtration, catalytic carbon absorption, electrochemical oxidation, wet oxidation, biological oxidation, and chemical oxidation techniques [29]. Chemical oxidation technologies are usually classified into conventional chemical oxidation and advanced oxidation processes [29].

\section{Chemical treatment}

There are several different technologies for the adsorption of $\mathrm{RhB}$ dye, including chemical oxidation, ion exchange, chemical precipitation, and photocatalytic degradation, etc. Although, according to its versatility, adsorption is considered a worldwide recommended water treatment technology [18].

(i) Conventional chemical methods such as microemulsion, co-chemical precipitation system, chemical hydrothermal procedure, thermal dissolving process, and the mechanical chemical process often used in dyes lysis are expensive. The adsorption process is beneficial and popular among all methods because it is low cost, highly effective, and easy to operate $[6,30]$.

(ii) Chemical agents for treating dye wastewater involve adding ozonation, ion exchange, and reducing agents. Hence, the improvement of cost-effective techniques is of most extreme significance in treating wastewaters that contain dye [31]. By previous experiments on the adsorption of $\mathrm{RhB}$, we can differently research several chemical approaches. Nanometer-wide metal oxides such as $\mathrm{TiO}_{2}, \mathrm{MnO}_{2}$,
$\mathrm{CeO}_{2}, \mathrm{MgO}, \mathrm{Al}_{2} \mathrm{O}_{3}, \mathrm{Fe}_{2} \mathrm{O}_{3}$, etc., are classified as suitable photocatalysts for wastewater treatment [6]. The preparation of carbon nanomaterials (NPCs) using the template method has also become increasingly important in recent years.

In general, the materials have a broad surface, porous sizes, good chemical, and thermal stability. Therefore, they are very promising absorbents for wastewater treatment. Also, industrial carbon has been labeled and used as an adsorbent to remove RhB from water [32]. Over the past few years, due to their extraordinarily high surface area, metal-organic frameworks (MOFs) have emerged as a promising alternative adsorbent for dye wastewater treatment due to their large surface area and good chemical tenability $[11,33]$. Since organic coloring is complicated to extract because it is hard to decompose, there are many methods for removing the dyes from environmental matrices. A photocatalytic method is a modern way to convert organic coloring to $\mathrm{CO}_{2}$ and $\mathrm{H}_{2} \mathrm{O}$ as final products. $\mathrm{Ag}_{3} \mathrm{PO}_{4} / \mathrm{Bi}_{2} \mathrm{WO}_{6}$ nanocomposites and $\mathrm{Co}_{1-\mathrm{x}} \mathrm{Cu}_{\mathrm{x}} \mathrm{Fe}_{2} \mathrm{O}_{4}(0$ $\leq \mathrm{x} \leq 0.5)$ nanoparticles have been synthesized for photolysis of $\mathrm{RhB}$ dye under visible irradiation [34-35]. Different types of adsorbents have been used to adsorb $\mathrm{RhB}$ dye from aqueous solutions. Synthesizing $\mathrm{MgO}-$ supported Fe-Co-Mn nanoparticles (MgO-FCM-NPs) are used as an adsorbent to extract $\mathrm{RhB}$ dye. Various techniques were used to test MgO-FCM-NPs, such as scanning electron microscopy (SEM), vibration sample magnetization (VSM), X-ray diffraction (XRD), and Fourier-transform infrared spectroscopy (FTIR) [36].

\section{Physical methods}

There has been comprehensive research into traditional physical treatment methods such as adsorption, filtration, electrolysis, and reverse osmosis for $\mathrm{RhB}$ dye adsorption. Adsorption technology continues to be sustainable, effective, and the safest strategy to resolve the challenges of the alarming rise in urbanization and industrialization [21,37-40]. Activated carbon $(\mathrm{AC})$ is known for its superior surface areas and microporous structures that contribute to the higher capacity of adsorption of $\mathrm{RhB}$ dye [17,41-43]. Membrane separation, for its simple operation process, 
small space occupancy, and low energy consumption, is considered a promising technology for dye wastewater [9]. Many studies have concentrated on advanced electrochemical oxidation processes (EAOPs), such as the electro-Fenton (EF) method. Moreover, an assortment of combined strategies was created, counting the coupling of EAOPs with photocatalysis, adsorption, nano-filtration, ultrasounds and microwaves, and the application of microbial fuel cells $[27,44]$. Numerous ponders were centered on electrochemical progressed oxidation forms (EAOPs) like electro-Fenton (EF) prepare. EF prepare might overcome these issues by the in situ electrochemical eras of $\mathrm{H}_{2} \mathrm{O}_{2}$ in the cathode [27].

Since the residual pigments in the wastewater are characterized by strong color, high organic content, and stable chemical structure due to azo functional groups. There are several different ways to extract dye from wastewater. Therefore, the use of electrochemical processes as an innovative option is for extracting dyes from colored effluents. The material of the anode has been shown to play a vital role in the electrolysis of organic contaminants for the removal of dye from the effluent. The dimensionally stable anode (DSA) is made of a base metal titanium coated with thin conductive ruthenium or iridium oxide. DSA anode achieves performance with high chemical stability even at high current densities, has a longer life, is commercially available, and at low cost [45]. Semiconductor photocatalysts have gotten expanding attention owing to their application in natural contamination treatment [46].

\section{Biological treatment}

Biological studies are an example of many critical biological methods for the adsorption and treatment of $\mathrm{RhB}$ dye from wastewater. Physical adsorption by degradation is commonly used in the treatment of effluents [41]. The biological water treatment methods have been less successful because most synthetic dyes are stable to heat and light. Also, many dyes are biologically not degradable because of their complex polymeric structure. In general, the dyes chosen by industries have good stability and fastness [47].

Several tons of dyes are gradually being dumped into wastewater. Discharge of wastewater rich in untreated or partially treated dyes into the natural environment is a major concern due to their respiratory infections and allergic reactions. Among these dyes, $\mathrm{RhB}$ [48] is broadly utilized in material passing on and in research facilities as a biological recolor [49]. The biological aerated filter (BAF) has played an important role in treating wastewater to extract $\mathrm{RhB}$ dye for many years. However, multiple adsorbents with an adsorption potential have been used to separate RhB dye [41].

\section{Different Adsorbents for the Removal of RhB Dye}

A wide range of solid raw agricultural residues has been discovered for the adsorption of RhB dye, such as pine and grapefruit peel, canola peel, peanut husk, pistachio nuts, and red peelings. Abundance in nature is one of the most important factors to consider before investigating various raw agricultural solid waste as lowcost absorbents. Banana, potato, and cucumber are among the agricultural products that are widely grown internationally, and their peels were examined on farmland for treating wastewater from dyes. However, their structure and surface chemistry effect on their ability to absorb the anionic and cationic dyes has been studied [37].

Studies recommend that adsorbents are promising approaches to treating colored effluents, including residual agricultural and industrial materials such as activated carbon from the wood residue, sawdust, and rice husks. Also, the previous studies referred that adsorption using biological materials such as microalgae is excellent removal of pigments. For example, the microalgae species Chlorella pyrenoids belonging to the Chlorophyta division have been used as an important bio-absorbent for removing $\mathrm{RhB}$ [13].

The effectiveness of this process was tested by using magnetite/carbon nanocomposite as a sorbent to extract anionic and cationic dyes from wastewater. As far as organic contaminants are concerned, pigments have a high potential to alter the environment due to their high color and optical emission. They also cause changes in biological cycles that primarily impact photosynthesis processes [28]. Subsequently, it is essential to minimize their concentration in wastewater to a more 
secure constrain [49]. Therefore, there is an urgent need for various adsorbents to quickly remove toxic pollutants from the environment, efficiently and affordable.

\section{Organic adsorbents}

Agricultural wastes. Researchers have used various biomass-based adsorbents to remove different dyes during the last ten years, including $\mathrm{RhB}$ dye from aquatic environments [50-51]. Several agricultural wastes and biomasses include Artocarpus odoratissimus, coffee beans, banana, orange, lignocellulosic, pomegranate, potato, and cucumber peels [50-56].

Artocarpus odoratissimus, locally known as Tarp in Brunei Darussalam, has been used to remove RhB from aqueous solutions. The skin and core are discarded as wastes. Therefore, they can utilize as adsorbents to reduce the waste disposal problems while converting the wastes into useful adsorbents to clean up wastewater. It has been successfully used as an adsorbent to remove $\mathrm{RhB}$ dye from an aqueous solution [57]. Banana peels as an adsorbent have many advantages for removing various toxins from water due to their cost-effective, plentiful, and high carbon and the disposal of banana peels. Banana is one of the most eaten fruits in the world. However, many banana peels are wasted every year despite numerous uses, and their disposal poses a serious issue. Therefore, recent research focuses on the adsorption of $\mathrm{RhB}$ dye to the prepared, environmentally friendly green banana peel powder [48].

Moreover, a systematic comparison of potato and cucumber peels' surface and structural properties as effective natural adsorbents was performed in some research to remove both ionic and cationic dyes such as $\mathrm{RhB}$ dye from the aqueous solutions [37]. In addition, coffee beans are widely produced and used exceeding 150 million of $60 \mathrm{~kg}$ bags which means plenty of waste coffee ground. The carbonized coffee grounds can be used for adsorption, soil remediation, and removing dangerous organic and inorganic compounds from aqueous or wastewater. Furthermore, the coffee ground powder is efficiently used as a zero-cost adsorbent for adsorption and subsequent removal of RhB dye from aqueous solutions [58].

Besides, adsorption is the favored strategy for treating color wastewater which depends on the choice of adsorbents and the adsorption capacities. The reason for choosing Casuarina equisetifolia cone (CEC) could be a sort of nonluminous plant, where the root depended on microscopic organisms, Frankie spp. Furthermore, CEC is found in nature in abundance, so it has a small economic value. Moreover, CEC can be effectively prepared into powder for adsorption due to its brittleness. It contains lignocellulosic fabric, which is one of the materials known to be included in the adsorption of poisons. Thus, choosing CEC as an adsorbent to evacuate poison may be an economical choice [59].

Carbon materials. Recently, considerable numbers of adsorbents have been used in removing different dyes, including RhB dye. Among those adsorbents, activated carbon exhibited several advantages. High surface area, porosity, and chemical properties are all responsible for its higher adsorption capacity in wastewater treatment with organic dye molecules [60-61]. Most carbon adsorbents are generated from fruit peels, sugar, beans, and zeolites [62-65]. White sugar undergoing the acid dehydration method was used to prepare a highly porous carbon. The carbon then gets activated in a nitrogen environment, which gives the activated sugarbased carbon (ASC). The ASC was characterized using some classical characterization techniques such as X-ray diffraction (XRD), Brumaire-Emmett-Teller (BET), and Fourier Transform Infrared (FTIR). The obtained result reveals that the pore parameters of the ASC were considered adequate for adsorption.

The obtained findings reveal that the pore parameters of the ASC were considered adequate for adsorption; for instance, $1144.77 \mathrm{~m}^{2} / \mathrm{g}, 0.53 \mathrm{~cm}^{3} / \mathrm{g}$, and $2.17 \mathrm{~nm}$ were recorded for surface area, the volume, and size of the pore, individually. Furthermore, ASC was used to remove $\mathrm{RhB}$ dye, and the results showed maximum adsorption efficiency of about $98.28 \%$ and an adsorption capacity of $123.46 \mathrm{mg} / \mathrm{g}$ within $12 \mathrm{~min}$ contact time. $\mathrm{RhB}$ adsorption onto ASC followed Langmuir isotherm and pseudo-second-order models. It was found to be regenerated up to 7-times, and the data related to the equilibrium and kinetic., respectively [17]. Also known as the African locust bean, a dicotyledonous angiosperm belonging to the family 
Fabaceae is Parkia biglobosa. It is classified under spermatophytes, i.e., vascular plants usually referred to in the beginning as locust beans. They are pink and, when fully grown, turn dark brown. On average, they are 30-40 $\mathrm{cm}$ long, with some reaching lengths of about $45 \mathrm{~cm}$. A novel adsorbent for $\mathrm{RhB}$ dye removal uses activated carbon prepared from the locust bean pod. The goal was to turn locus bean pod biomass waste into AC by preparing a superior functionalized adsorbent to remove RhB dye from the aqueous solutions. The kinetic, isothermal, and thermodynamic parameters regulating the adsorption mechanism have also been examined [41].

In addition, zeolites from Brazilian coal fiery remains have been utilized as a successful low-cost adsorbent in numerous applications. Zeolites have lasting negative charges in their precious stone structures, which empower them to be adjusted by cationic surfactants, such as hexadecyltrimethylammonium [51]. Furthermore, the alteration of the zeolitic fabric improves the expulsion of natural and anionic poisons from effluents [65].

Besides, researchers are paying attention nowadays to biochar carbon materials to remove organic dyes from wastewater. This is due to their inexpensive cost and stability, and sustainability [66-68]. Moreover, the carbon-rich plantain peel (PP) is approximately 30 percent of the plantain fruit. Salts such as sodium chloride and zinc chloride activated PP biochar using ferric nitrate, as well as acids and bases, can be used as chemical activating agents. PP is a waste without any economic value and is generally friendly environmental. For the removal of $\mathrm{RhB}$ from wastewater, prepared activated biochar has been used [69]. Moreover, the preparation of biochar from bamboo shoot shell (BSS) hydrothermal carbonization to obtain hydrocar, followed by a treatment for high-temperature carbonization, has been reported to evaluate biochar's ability to remove $\mathrm{RhB}$ dye from wastewater. The main component of BSS is very similar to other types of woody biomass containing cellulose, hemicellulose, and lignin, an ideal raw material for carbon material production [42].

Likewise, agricultural waste cassava slag was used to develop cassava slag biochar by hydrothermal technique carbonization process. The structural properties, adsorption performance, and mechanism were comprehensively investigated with multiple tools, such as Scanning Electron Microscopy (SEM), Leica microscope, Brunauer-Emmett-Teller (BET), batch adsorption experiments, Fourier-transform infrared (FTIR), and Xray photoelectron spectroscopy (XPS). The results from the experiment showed that the cassava slag biochar could remove $96 \%$ of $\mathrm{RhB}$ from an aqueous solution, with a maximum adsorption amount of $105.3 \mathrm{mg} / \mathrm{g}$. The good adsorption efficiency of RhB could be due to intermolecular hydrogen bonding and electrostatic interaction. In addition, for different colors, the cassava slag biochar has indicated an excellent adsorption efficiency and was economically practical in engineering applications, suggesting a great potential in functional operations [70].

\section{Inorganic adsorbents}

Inorganic adsorbents such as zeolites, clays, and perlite are natural, low-cost, abundant, and sustainable materials used in the adsorption process to remove dyes [51,71]. Zeolites naturally occur as porous aluminosilicates consisting of different structures linked together by a shared oxygen atom. The use of zeolite as an adsorbent is available in various types. The $3 \mathrm{~A}$ zeolite was assessed as a promising adsorbent for the removal of $\mathrm{RhB}$ samples from wastewater. Taguchi configuration of the experiment is a multivariate optimization method used to optimize effective parameters. It is a very successful approach and has some benefits over conventional univariate optimization strategies, such as minimizing experimental costs and reducing practical research time [72]. As a synthetic zeolite, beta zeolite is one of the most widely used molecular sieves, particularly in adsorption due to many important characteristics, such as large pores, high $\mathrm{Si} / \mathrm{Al}$ ratio, and three-dimensional pore networks. Therefore, adsorption materials based on graphene oxide/Beta zeolite composite materials and their adsorption performance for RhB have been studied [73].

Clays are fine-grained minerals, there are around 30 different types of clays, but most "natural" clays are mixtures of these different types. They have a high special surface area and a high potential of cation 
exchange potential [74]. Therefore, they have been widely used as sorbents to remove various forms of pollutants. Clay can remove up to $70 \%$ of the wastewater. Modified Moroccan natural clay with cetyltrimethylammonium bromide has been investigated for $\mathrm{RhB}$ dye removal $[49,75]$. The quests showed that clay minerals are effective absorbents for removing cationic dyes such as $\mathrm{RhB}$ dye from water [7].

In addition to that, expanded perlite has been used to treat wastewater from RhB. It has also been studied applying pseudo-first-order, pseudo-second-order, and intra-part-diffusion models. The results showed that the sorption mechanism was better fitted with a pseudosecond-order model. To describe the phenomenon of adsorption, adsorption isotherms models, e.g., Langmuir, Freundlich, and Temkin, and thermodynamic studies were applied. In addition, the UV spectrophotometric technique is used for the determination of $\mathrm{RhB}$. The results have shown that expanded perlite is a suitable adsorbent for removing $\mathrm{RhB}$ from aqueous solutions. The quantity removed was depended on the initial concentration, contact time, solution temperature, and $\mathrm{pH}$ of the solution [9]. Besides, paper industries produce a large amount of sludge every year, which can be used as an adsorbent to remove dyes. Therefore, it can be considered a promising, eco-friendly adsorbent with lowcost production to remove dyes from wastewater in a short time. Response surface optimization of RhB dye removal using paper industry waste as adsorbent has been investigated [76].

Moreover, $\mathrm{SiO}_{2} / \mathrm{TiO}_{2}$ particles were synthesized and coated with white Portland cement paste on the surface, with RhB degradation tests examining the photocatalytic efficiencies of treated pastes before and after an accelerated weathering process. Via investigations of its pozzolanic reactions with the major components of cement concrete, bonding, and its mechanisms on hardened cement-based materials were studied [30]. Also, a typical $\mathrm{Zr}-\mathrm{MOF}$ (bpy) material has nitrogen atoms that can form hydrogen bonds with the carboxyl groups found on $\mathrm{RhB}$ dye to be removed. The addition of $\mathrm{ZnO}$ nanoparticles to $\mathrm{Zr}-\mathrm{MOF}$ (bpy) during growth $\mathrm{Zr}$ MOF(bpy) synthesis aided its gelation and created the gel- like $\mathrm{ZnO} / \mathrm{Zr}-\mathrm{MOF}$ (bpy) nanocomposite. This addition enhanced RhB dye adsorption appropriately [77].

Similarly, synthesized $\mathrm{ZnFe}_{2} \mathrm{O}_{4}$ nanocomposite was used as an adsorbent to remove $\mathrm{RhB}$, characterized by SEM, BET, and FTIR. The parameter effects that were studied are initial $\mathrm{RhB}$ concentration $\left(5-25 \mathrm{mg} \mathrm{L}^{-1}\right), \mathrm{pH}$ (3.4-11.1), and temperature $\left(20-60^{\circ} \mathrm{C}\right)$. At equilibrium, the adsorption capacity increased from 5.02 to $9.83 \mathrm{mg}$ $\mathrm{g}^{-1}$, with the increasing amount of initial concentration of $\mathrm{RhB}$ from 5 to $25 \mathrm{mg} \mathrm{L}^{-1}$ at $\mathrm{pH} 7.0$ and $20^{\circ} \mathrm{C}$. The experimental results showed that at a solution $\mathrm{pH}$ of 4.4 and the adsorption capacity obtained was $6.02 \mathrm{mg} \mathrm{g}^{-1}$, and the maximum Rhodamine $B$ removal could be achieved. Among the pseudo-first-order kinetic, the pseudo-second-order, and the intraparticle diffusion models, it was best fitted using a pseudo-second-order kinetic model. The adsorption of $\mathrm{RhB}$ onto $\mathrm{ZnFe}-\mathrm{NC}$ was also analyzed using both Langmuir and Freundlich isotherm model. In addition, various thermodynamic parameters, such as standard Gibbs free energy $\left(\Delta \mathrm{G}^{\circ}\right)$, enthalpy $\left(\Delta \mathrm{H}^{\circ}\right)$, and entropy $\left(\Delta \mathrm{S}^{\circ}\right)$, have also been calculated [78].

Cobalt ferrite is cubic inverse spinel and occupied a prominent place in photocatalysis, with characteristic behavior and a narrow bandgap range of $1.1-2.3 \mathrm{eV}$. The characteristic feature of cobalt ferrite is high coercivity, moderate saturation, large magnetocrystalline anisotropy, and large magnetostrictive coefficient at room temperature. The microwave combustion method is one of the most effective and feasible methods for preparing copper-doped cobalt ferrite nanoparticles. They focused on preparing copper doped cobalt ferrite nanoparticles by microwave combustion method employing L-arginine as fuel and studying the structural, morphological, optical, vibrational, and magnetic properties of $\mathrm{Co}_{1-\mathrm{x}} \mathrm{Cu}_{\mathrm{x}} \mathrm{Fe}_{2} \mathrm{O}_{4}(0 \leq \mathrm{x} \leq 0.5)$ nanoparticles by various characterization techniques. The prepared materials were employed for the photocatalytic degradation of $\mathrm{RhB}$ under visible light irradiation and a suitable degradation mechanism is proposed [34].

Likewise, recent researches describe the synthesis of magnetic $\mathrm{Fe}_{2} \mathrm{O}_{3}$ and $\mathrm{Fe}_{2} \mathrm{O}_{3} / \mathrm{g}-\mathrm{C}_{3} \mathrm{~N}_{4}$ monoliths prepared by implementing the nano casting and vacuum 
impregnation methods, individually. For examining the magnetic potentiality of the monoliths, vibrating sample magnetometer (VSM) analysis was used. The monoliths have great significance in wastewater treatment applications because of their nature to easily separate. The toxic dye, i.e., $\mathrm{RhB}$, has been removed photo catalytically from the aqueous medium using the synthesized monoliths. $\mathrm{Fe}_{2} \mathrm{O}_{3} / g-\mathrm{C}_{3} \mathrm{~N}_{4}$ monolith degradation efficiency was $94.7 \%$ in $140 \mathrm{~min}$ at $\mathrm{pH} \sim 7$ under visible light. This was assigned because the monoliths, along with the efficient charge separation efficiency, exhibited a porous nature, which increases their catalytic activity. Moreover, the monolithic catalysts showed excellent stability and reusability over several studies of degradation processes [79].

Moreover, L-Serine (L-Ser) capped magnetite nanoparticles $\left(\mathrm{Fe}_{3} \mathrm{O}_{4} \mathrm{NPs}\right)$ is a green one-pot synthesis. It has potential application for the adsorption of $\mathrm{RhB}$ dye from an aqueous solution. Due to their high surface area to volume ratio, nanostructured materials can easily functionalize their surface by different molecules for efficient adsorption. Moreover, its unique structural, electrical, optical, and magnetic properties can provide outstanding opportunities for the adsorption of dyes. The study of facile green synthesis of L-Ser capped $\mathrm{Fe}_{3} \mathrm{O}_{4} \mathrm{NPs}$ via a coprecipitation of $\mathrm{Fe}_{3} \mathrm{C}$ and $\mathrm{Fe}_{2} \mathrm{C}$ salts in the presence of L-Ser as a capping agent. The as-synthesized L-Ser capped $\mathrm{Fe}_{3} \mathrm{O}_{4}$ NPs were characterized by using UVVisible Spectrophotometry [47]. Furthermore, recent research found that uranyl-organic frameworks are good candidates for removing such chemical pollutants. Part of the uranyl-organic frameworks, heterometallic uranylbased (such as Ni-U, Ag-U) photocatalysts, have excellent photocatalytic activities for degradation of $\mathrm{RhB}$ under UV/visible light irradiation [80].

Additionally, impregnation of $\mathrm{TiO}_{2}$ and bentonite followed by microwave irradiation processes is the way for preparing bentonite- $\mathrm{TiO}_{2}$ composites, characterized by XRD, FTIR, and SEM. Liquid phase adsorption of RhB was used to study the adsorption and photocatalytic capabilities of the composites. The adsorption and photocatalytic degradation experiments were conducted in the presence or absence of UV light irradiation [81].
Also, $\mathrm{Cu}_{2} \mathrm{O} / \mathrm{rGO}$ nanocomposites would have $\mathrm{Cu}_{2} \mathrm{O}$ nanoparticles distributed evenly on reduced graphene oxide (rGO). It was fabricated by a facile in-situ wetreduced method. The crystalline and photoluminescence structures of $\mathrm{Cu}_{2} \mathrm{O} / \mathrm{rGO}$ nanocomposites have been analyzed and characterized. Comparing $\mathrm{Cu}_{2} \mathrm{O} / \mathrm{rGO}$ nanocomposites with the pure $\mathrm{Cu}_{2} \mathrm{O}$ nanoparticles, the corresponding removal percentage of $\mathrm{RhB}$ achieved more than $95 \%$ showing good photocatalytic activity of the $\mathrm{Cu}_{2} \mathrm{O} / \mathrm{rGO}$ nanocomposites. A mechanism for photocatalytic of the $\mathrm{Cu}_{2} \mathrm{O} / \mathrm{GO}$ nanocomposites activity could be ascribed to the enhanced adsorption intensity and effective charge carriers separation by rGO [82].

Recently, and due to economic concerns, functionalized polymeric resins have become an alternative to activated carbon and other absorbents. Characterizing polymeric resins is done by their high surface area, moderate swelling, and narrow pore size distribution. Improving the adsorption of resins can be done by modification using the interaction between adsorbate and adsorbent. Mainly, for it is comparatively lower in cost than activated carbon and serves several advantages as a matrix, styrene-divinylbenzene crosslinked copolymer was used to prepare ion-exchange resins. Additionally, the polystyrene-based matrix can provide excellent chemical and physical stability together with resistance to degradation by oxidation or hydrolysis.

Moreover, solvent impregnated resins (SIR) are synergistic properties of both ion exchange and solvent extraction. SIR is defined as a liquid complexing agent distributed homogenously in a solid polymeric medium. The removal with SIR processes happens when a solute is extracted from the aqueous phase into the pores of the resin in an organic phase. As a result, the resin reduces the entrainment and irreversible emulsification during solvent extraction as it acts as a carrier of the solvent [83]. Therefore, the removal of $\mathrm{RhB}$ dye from water using a solvent impregnated polymeric Dowex 5WX8 resin has been achieved [83]. The tables below summarize the analytical features of experimental, thermodynamic, isothermal, and kinetic parameters of adsorption from 2016 to 2020 . 
Table 2. Analytical features of experimental and thermodynamic parameters of adsorption RhB by different techniques during 2016

\begin{tabular}{|c|c|c|c|c|c|c|c|c|c|c|c|}
\hline \multirow[b]{2}{*}{ Adsorbent } & \multicolumn{6}{|c|}{ Experimental Parameters } & \multicolumn{5}{|c|}{ Thermodynamic } \\
\hline & $\begin{array}{c}Q_{\max } \\
(\mathrm{mg} / \mathrm{g})\end{array}$ & $\mathrm{pH}$ & $\begin{array}{c}\mathrm{T} \\
\left({ }^{\circ} \mathrm{C}\right)\end{array}$ & $\begin{array}{c}\mathrm{Co} \\
(\mathrm{mg} / \mathrm{L})\end{array}$ & $\begin{array}{c}\mathrm{T} \\
(\min )\end{array}$ & $\begin{array}{c}\mathrm{AD} \\
(\mathrm{g} / \mathrm{L})\end{array}$ & Model & $\begin{array}{c}\Delta \mathrm{G}^{\circ} \\
(\mathrm{kJ} / \mathrm{mol})\end{array}$ & $\begin{array}{c}\Delta \mathrm{H}^{\circ} \\
(\mathrm{kJ} / \mathrm{mol})\end{array}$ & $\begin{array}{c}\Delta \mathrm{S}^{\circ} \\
(\mathrm{J} / \mathrm{mol} \mathrm{K})\end{array}$ & Ref. \\
\hline $\begin{array}{l}\text { Casuarina equisetifolia } \\
\text { Cone Powder }\end{array}$ & 49.5 & 2 & 25 & 50 & 30 & 0.05 & $\mathrm{~L}, \mathrm{~F}$, and $\mathrm{S}$ & -0.1 & 14.19 & 51.16 & [59] \\
\hline $\begin{array}{l}\text { Raphia hookerie fruit } \\
\text { epicarp }\end{array}$ & 666.6 & 3 & 26 & 100 & 50 & 2 & $\begin{array}{l}\mathrm{L}, \mathrm{F}, \mathrm{T} \text {, and } \\
\mathrm{DR}\end{array}$ & -3.1 & 11.74 & 49.23 & {$[8]$} \\
\hline Azolla pinnata & 199.7 & 3.6 & 65 & $20-600$ & 30 & 2 & $\mathrm{~L}, \mathrm{~F}, \mathrm{DR}, \mathrm{T}$ & -0.6 & 23.3 & 80.4 & {$[84]$} \\
\hline $\begin{array}{l}\text { Casuarina equisetifolia } \\
\text { needles }\end{array}$ & 82.34 & 4.4 & 25 & 50 & 180 & 0.04 & $\mathrm{~L}, \mathrm{~F}$, and $\mathrm{DR}$ & -2.2 & 20.1 & 75 & {$[85]$} \\
\hline $\begin{array}{l}\mathrm{Bi}_{2} \mathrm{O}_{3} \text {-bentonite } \\
\text { nanocomposite }\end{array}$ & 69 & 3 & 400 & 20 & 80 & 1 & $\mathrm{~L}$ and $\mathrm{F}$ & NA & NA & NA & {$[16]$} \\
\hline $\begin{array}{l}\text { Aleurites Moluccana } \\
\text { Waste Seeds }\end{array}$ & 117 & 6 & 25 & 300 & 60 & 0.05 & $\begin{array}{l}\text { L, F, S, and } \\
\text { R-B }\end{array}$ & 5.0 & -12.9 & -57.12 & [86] \\
\hline $\begin{array}{l}\text { Surfactant-modified } \\
\text { zeolite }\end{array}$ & 0.388 & 8 & 45 & 20 & 40 & 0.5 & $\begin{array}{l}\mathrm{L}, \mathrm{F}, \mathrm{T} \text {, and } \\
\mathrm{D}-\mathrm{R}\end{array}$ & -24 & NA & NA & {$[65]$} \\
\hline
\end{tabular}

Qmax: Maximum adsorption of RhB adsorbed per unit mass of adsorbent after equilibrium $\left(\mathrm{mg} \mathrm{g}^{-1}\right)$, $\mathrm{T}\left({ }^{\circ} \mathrm{C}\right)$ : Temperature, Co: Initial Concentration (mg $\left.\mathrm{L}^{-1}\right)$, $\mathrm{T}$ (min): Equilibrium Contact Time, AD: Adsorbent dosage $\left(\mathrm{g} \mathrm{L}^{-1}\right), \Delta \mathrm{G}^{\circ}$ : Standard Gibbs free energy $\left(\mathrm{kJ} \mathrm{mol}^{-1}\right), \Delta \mathrm{H}^{\circ}$ : Standard enthalpy $\left(\mathrm{kJ}\right.$ mol $\left.{ }^{-1}\right), \Delta \mathrm{S}^{\circ}$ : Standard entropy $\left(\mathrm{J} \mathrm{mol}^{-1} \mathrm{~K}^{-1}\right)$, L: Langmuir isotherm model, F: Freundlich Isotherm model and DR: Dubinin-Radushkevich. NA: Not Achieved

Table 3. Analytical features of isothermal and kinetic parameters of adsorption RhB by different techniques during 2016

\begin{tabular}{|c|c|c|c|c|c|c|c|c|c|c|c|c|c|c|}
\hline \multirow{3}{*}{ Adsorbent } & \multicolumn{7}{|c|}{ Isotherm } & \multicolumn{6}{|c|}{ Kinetic parameter } & \multirow{3}{*}{ Ref. } \\
\hline & \multicolumn{4}{|c|}{ Langmuir } & \multicolumn{3}{|c|}{ Freundlich } & \multicolumn{3}{|c|}{ Pseudo-first order } & \multicolumn{3}{|c|}{ Pseudo-second order } & \\
\hline & $\begin{array}{c}\mathrm{q}_{\mathrm{m}} \\
(\mathrm{mg} / \mathrm{g}) \\
\end{array}$ & $\begin{array}{c}\mathrm{k}_{\mathrm{L}} \\
(\mathrm{L} / \mathrm{mg})\end{array}$ & $\mathrm{R}^{2}$ & $\mathrm{R}_{\mathrm{L}}$ & $\mathrm{K}_{\mathrm{F}}$ & $\mathrm{n}$ & $\mathrm{R}^{2}$ & $\begin{array}{c}\mathrm{K}_{1} \\
\left(\mathrm{~min}^{-1}\right)\end{array}$ & $\begin{array}{c}\begin{array}{c}\mathrm{q}_{\mathrm{e}} \\
(\mathrm{mg} / \mathrm{g})\end{array} \\
\end{array}$ & $\mathrm{R}^{2}$ & $\begin{array}{c}\mathrm{K}_{2} \\
(\mathrm{~g} / \mathrm{min} \mathrm{mg}) \\
\end{array}$ & $\begin{array}{c}\mathrm{q}_{\mathrm{e}} \\
(\mathrm{mg} / \mathrm{g})\end{array}$ & $\mathrm{R}^{2}$ & \\
\hline $\begin{array}{l}\text { Casuarina } \\
\text { equisetifolia Cone } \\
\text { Powder }\end{array}$ & 49.5 & 0.033 & 0.993 & 0.057 & 4.087 & 2.21 & 0.900 & 0.018 & 8.22 & 0.919 & 0.004 & 11.5 & 0.985 & [59] \\
\hline $\begin{array}{l}\text { Raphia hookerie fruit } \\
\text { epicarp }\end{array}$ & 666.6 & 0.01 & 0.9876 & 0.19 & 10.55 & 1.29 & 0.9969 & 0.038 & 25.2 & 0.984 & 0.0033 & 47.1 & 0.9820 & {$[8]$} \\
\hline Azolla pinnata & 72.2 & 0.001 & 0.986 & 0.085 & 4.3 & 2.1 & 0.925 & 0.001 & 18.4 & 0.977 & 0.0020 & 31.5 & 0.995 & [84] \\
\hline $\begin{array}{l}\text { Casuarina } \\
\text { equisetifolia needles }\end{array}$ & 82.34 & 0.02 & 0.99 & 0.11 & 3.73 & 1.90 & 0.950 & 7.2 & 0.09 & 0.801 & 0.040 & 7.2 & 0.999 & [85] \\
\hline $\begin{array}{l}\mathrm{Bi}_{2} \mathrm{O}_{3} \text {-bentonite } \\
\text { nanocomposite }\end{array}$ & 31.25 & 0.727 & 0.892 & 0.0643 & 12.62 & 0.49 & 0.944 & 0.07 & NA & NA & 0.004 & NA & NA & [16] \\
\hline $\begin{array}{l}\text { Aleurites Moluccana } \\
\text { waste seeds }\end{array}$ & 101 & 0.003 & 0.996 & NA & 2.8 & 0.4 & 0.962 & 0.06 & 21.2 & 0.866 & 0.004 & 23.6 & 0.949 & [86] \\
\hline $\begin{array}{l}\text { Surfactant-modified } \\
\text { zeolite }\end{array}$ & 2.03 & 0.041 & 0.067 & NA & 0.110 & 1.38 & 0.900 & 0.004 & 0.01 & 0.219 & 1.02 & 0.23 & 0.990 & [65] \\
\hline
\end{tabular}

$\mathrm{q}_{\mathrm{m}}$ : Monolayer maximum adsorption capacity of RhB per unit mass of sorbent $\left(\mathrm{mg} \mathrm{g}^{-1}\right)$ and $\mathrm{K}_{\mathrm{L}}$ : Langmuir constant related to the binding energy of RhB sorption $\left(\mathrm{L} \mathrm{mg}^{-1}\right), \mathrm{R}_{\mathrm{L}}$ : indicates the dimensionless separation factor, $\mathrm{K}_{\mathrm{F}}$ : adsorption capacity of the sorbent $\left(\mathrm{L} \mathrm{g}^{-1}\right)$, $\mathrm{n}$ : gives an indication of how favorable the adsorption process in terms of surface heterogeneity and affinity for the adsorbate, $\mathrm{q}_{\mathrm{e}}$ : Equilibrium quantity of adsorbate per unit mass of the sorbent (mg $\mathrm{g}^{-1}$ ), $\mathrm{K}_{1}$ : First-order kinetic model $\left(\mathrm{min}^{-1}\right), \mathrm{K}_{2}$ : Second-order kinetic model $\left(\mathrm{g}(\mathrm{mg} \mathrm{min})^{-1}\right)$, and $\mathrm{R}^{2}$ : Correlation factor and NA: Not achieved

Table 4. Analytical features of experimental and thermodynamic parameters of adsorption RhB by different techniques during 2017

\begin{tabular}{|c|c|c|c|c|c|c|c|c|c|c|c|}
\hline \multirow[b]{2}{*}{ Adsorbents } & \multicolumn{7}{|c|}{ Experimental parameters } & \multicolumn{3}{|c|}{ Thermodynamics } & \multirow[b]{2}{*}{ Ref. } \\
\hline & $\begin{array}{c}\mathrm{Q}_{\max } \\
(\mathrm{mg} / \mathrm{g})\end{array}$ & $\mathrm{pH}$ & $\mathrm{T}(\mathrm{K})$ & $\mathrm{C}^{\mathrm{o}}(\mathrm{mg} / \mathrm{L})$ & $\begin{array}{c}\mathrm{T} \\
(\mathrm{min})\end{array}$ & $\begin{array}{c}\mathrm{AD} \\
(\mathrm{g} / \mathrm{L})\end{array}$ & Model & $\begin{array}{c}\Delta \mathrm{G}^{\circ} \\
(\mathrm{kJ} / \mathrm{mol})\end{array}$ & $\begin{array}{c}\Delta \mathrm{H}^{\circ} \\
(\mathrm{kJ} / \mathrm{mol})\end{array}$ & $\begin{array}{c}\Delta \mathrm{S}^{\circ} \\
(\mathrm{J} / \mathrm{mol} \mathrm{K})\end{array}$ & \\
\hline $\begin{array}{l}\text { Coal-based carbon membrane with } \\
\text { an electric field }\end{array}$ & NA & 4 & NA & 100 & 480 & NA & NA & NA & NA & NA & {$[9]$} \\
\hline Natural Moroccan Clay & 83.95 & $2-12$ & 298 & 20 & 270 & 0.01 & $\mathrm{~F}, \mathrm{~L}, \mathrm{Te}$ & 8.016 & 12.887 & 0.0701 & {$[75]$} \\
\hline Modified Moroccan Clay & 90.10 & $2-12$ & 298 & 20 & 270 & 0.01 & $\mathrm{~F}, \mathrm{~L}, \mathrm{Te}$ & 9.355 & 26.214 & 0.1193 & {$[75]$} \\
\hline
\end{tabular}


Table 4. Analytical features of experimental and thermodynamic parameters of adsorption RhB by different techniques during 2017 (Continued)

\begin{tabular}{|c|c|c|c|c|c|c|c|c|c|c|c|}
\hline \multirow[b]{2}{*}{ Adsorbents } & \multicolumn{7}{|c|}{ Experimental parameters } & \multicolumn{3}{|c|}{ Thermodynamics } & \multirow[b]{2}{*}{ Ref. } \\
\hline & $\begin{array}{c}\mathrm{Q}_{\max } \\
(\mathrm{mg} / \mathrm{g})\end{array}$ & $\mathrm{pH}$ & $\mathrm{T}(\mathrm{K})$ & $\mathrm{C}^{\circ}(\mathrm{mg} / \mathrm{L})$ & $\begin{array}{c}\mathrm{T} \\
(\min )\end{array}$ & $\begin{array}{l}\mathrm{AD} \\
(\mathrm{g} / \mathrm{L})\end{array}$ & Model & $\begin{array}{c}\Delta \mathrm{G}^{\circ} \\
(\mathrm{kJ} / \mathrm{mol})\end{array}$ & $\begin{array}{c}\Delta \mathrm{H}^{\circ} \\
(\mathrm{kJ} / \mathrm{mol})\end{array}$ & $\begin{array}{c}\Delta S^{\circ} \\
(\mathrm{J} / \mathrm{mol} \mathrm{K})\end{array}$ & \\
\hline $\begin{array}{l}\text { Coal-based carbon membrane with } \\
\text { an electric field }\end{array}$ & NA & 4 & NA & 100 & 480 & NA & NA & NA & NA & NA & {$[9]$} \\
\hline Natural Moroccan Clay & 83.95 & $2-12$ & 298 & 20 & 270 & 0.01 & $\mathrm{~F}, \mathrm{~L}, \mathrm{Te}$ & 8.016 & 12.887 & 0.0701 & [75] \\
\hline Modified Moroccan Clay & 90.10 & $2-12$ & 298 & 20 & 270 & 0.01 & $\mathrm{~F}, \mathrm{~L}, \mathrm{Te}$ & 9.355 & 26.214 & 0.1193 & [75] \\
\hline $\begin{array}{l}\mathrm{Co}_{1-\mathrm{x}} \mathrm{Cu}_{\mathrm{x}} \mathrm{Fe}_{2} \mathrm{O}_{4}(0 \leq \mathrm{x} \leq 0.5) \\
\text { nanoparticles }\end{array}$ & NA & 2 & 298 & 6 & 330 & 0.31 & $\mathrm{~K}_{1}, \mathrm{~K}_{2}$ & NA & NA & NA & {$[34]$} \\
\hline $\begin{array}{l}\text { L-Serine capped magnetite } \\
\text { nanoparticles }\end{array}$ & 6.82 & 7.4 & 300 & 10 & 60 & 2.18 & $\mathrm{~K}_{2}, \mathrm{~F}, \mathrm{~L}$ & -1.165 & 41.75 & 0.145 & {$[47]$} \\
\hline Artocarpus odoratissimus peel & 131 & 4.15 & 358 & $0-1000$ & 210 & 210 & $\mathrm{~L}$ & NA & 11.32 & 46.31 & [57] \\
\hline Coffee ground & $\begin{array}{l}3.02 \text { and } \\
1.661\end{array}$ & 2 & 292 & 15 & 180 & 50 & $\mathrm{~K}_{1}, \mathrm{~K}_{2}, \mathrm{~F}, \mathrm{~L}$ & 2.420 & 52.185 & 170.429 & [58] \\
\hline Paper waste & 75 & 4.4 & 308 & 75 & 60 & $0.5-2.5$ & $\mathrm{~K}_{2}, \mathrm{~L}$ & -11.94 & 11.70 & 0.0768 & [76] \\
\hline Graphene oxide/Beta zeolite & 64.47 & 6.5 & 330 & 0.1179 & 60 & 2.5 & F, L & NA & NA & NA & [73] \\
\hline Uranyl coordination polymer & 10 & 2.7 & 293 & $40-100$ & 270 & 0.157 & $\mathrm{~L}$ & NA & NA & NA & [80] \\
\hline $\mathrm{ZnFe}_{2} \mathrm{O}_{4}$ nanocomposite & 9.83 & 7 & 293 & 25 & 1440 & 12.1 & $\mathrm{~K}_{1}, \mathrm{~K}_{2}, \mathrm{~L}, \mathrm{~F}$ & -0.42 & 6.60 & 24 & [78] \\
\hline $\begin{array}{l}\text { Bentonite-titanium dioxide } \\
\text { composites }\end{array}$ & NA & 8 & 343 & 200 & 120 & 10.84 & F, L & NA & 14.56 & NA & {$[81]$} \\
\hline $\begin{array}{l}\text { Zinc oxide loaded activated carbon } \\
\text { (ZnO-AC) }\end{array}$ & 128.2 & 7 & 313 & 50 & 140 & 50 & $\mathrm{~K}_{1}, \mathrm{~K}_{2}, \mathrm{~F}, \mathrm{~L}$ & -11.0819 & 28.043 & 57.192 & [5] \\
\hline
\end{tabular}

$\mathrm{Q}_{\max }$ : Maximum adsorption of $\mathrm{RhB}$ adsorbed per unit mass of adsorbent after equilibrium $\left(\mathrm{mg} \mathrm{g}^{-1}\right), \mathrm{T}\left({ }^{\circ} \mathrm{C}\right)$ : Temperature, Co: Initial Concentration (mg L $\left.\mathrm{L}^{-1}\right)$, $\mathrm{T}(\mathrm{min})$ : Equilibrium Contact Time, A.D: Adsorbent dosage $\left(\mathrm{g} \mathrm{L}^{-1}\right), \Delta \mathrm{G}^{\circ}$ : Standard Gibbs free energy $\left(\mathrm{kJ} \mathrm{mol}^{-1}\right), \Delta \mathrm{H}^{\circ}$ : Standard enthalpy $\left(\mathrm{kJ}\right.$ mol $\left.{ }^{-1}\right), \Delta \mathrm{S}^{\circ}$ : Standard entropy $\left(\mathrm{J} \mathrm{mol}^{-1} \mathrm{~K}^{-1}\right)$, L: Langmuir isotherm model, F: Freundlich Isotherm model and DR: Dubinin-Radushkevich. NA: Not Achieved

Table 5. Analytical features of isothermal and kinetic parameters of adsorption RhB by different techniques during 2017

\begin{tabular}{|c|c|c|c|c|c|c|c|c|c|c|c|c|c|}
\hline \multirow[b]{3}{*}{ Adsorbents } & \multicolumn{6}{|c|}{ Kinetic parameters } & \multicolumn{6}{|c|}{ Isotherm parameters } & \multirow[b]{3}{*}{ Ref. } \\
\hline & \multicolumn{3}{|c|}{ pseudo-first order } & \multicolumn{3}{|c|}{ pseudo-second order } & \multicolumn{3}{|c|}{ Langmuir } & \multicolumn{3}{|c|}{ Freundlich } & \\
\hline & $\begin{array}{c}\mathrm{q}_{\mathrm{e}} \\
(\mathrm{mg} / \mathrm{g})\end{array}$ & $\begin{array}{c}\mathrm{K}_{1} \\
\left(\mathrm{~min}^{-1}\right)\end{array}$ & $\mathrm{R}^{2}$ & $\begin{array}{c}\mathrm{q}_{\mathrm{e}} \\
(\mathrm{mg} / \mathrm{g})\end{array}$ & $\begin{array}{c}\mathrm{K}_{2} \\
\left(\mathrm{~g} \mathrm{~min}^{-1}\right. \\
\left.\mathrm{mg}^{-1}\right)\end{array}$ & $\mathrm{R}^{2}$ & $\begin{array}{c}\mathrm{q}_{\mathrm{m}} \\
(\mathrm{mg} / \mathrm{g})\end{array}$ & $\begin{array}{c}\mathrm{K}_{\mathrm{L}} \\
(\mathrm{L} / \mathrm{g})\end{array}$ & $\mathrm{R}^{2}$ & $\mathrm{~K}_{\mathrm{F}}$ & $\mathrm{n}$ & $\mathrm{R}^{2}$ & \\
\hline Natural Moroccan Clay & 4.362 & 0.01 & 0.688 & 84.03 & 0.05 & 0.999 & 68.4 & -1.678 & 0.999 & 107 & -4.79 & 0.996 & [75] \\
\hline Modified Moroccan Clay & 3.526 & 0.07 & 0.9469 & 90.09 & 0.05 & 0.999 & 90.1 & 0.03 & 0.999 & 98.3 & -7.88 & 0.996 & [75] \\
\hline $\begin{array}{l}\mathrm{Co}_{1-\mathrm{x}} \mathrm{Cu}_{\mathrm{x}} \mathrm{Fe}_{2} \mathrm{O}_{4}(0 \leq \mathrm{x} \leq 0.5) \\
\text { nanoparticles }\end{array}$ & NA & 0.657 & 0.980 & NA & 0.86 & 0.958 & NA & NA & NA & NA & NA & NA & [34] \\
\hline L-Ser capped $\mathrm{Fe}_{3} \mathrm{O}_{4} \mathrm{NPs}$ & 6.11 & 0.01 & 0.9756 & 7.940 & 0.01 & 0.991 & 7.19 & $0.03-0.08$ & 0.991 & 7.19 & $0.03-0.08$ & 0.999 & [47] \\
\hline $\begin{array}{l}\text { Artocarpus odoratissimus } \\
\text { peel }\end{array}$ & NA & NA & NA & NA & NA & NA & 130 & 0.02 & 0.986 & NA & NA & NA & [57] \\
\hline Coffee ground & 4.018 & 37.9 & 0.999 & 4.018 & 6.56 & 0.999 & 5.25 & 4.364 & 0.958 & 1.19 & 2.06 & 0.884 & [58] \\
\hline Paper waste & NA & NA & NA & 3.74 & 0.69 & 1 & 6.71 & 0.01 & 0.996 & NA & NA & NA & [76] \\
\hline $\begin{array}{l}\text { Graphene oxide/Beta } \\
\text { zeolite }\end{array}$ & NA & NA & NA & NA & NA & NA & 27.9 & 0.080 & 0.992 & 2.53 & 1.83 & 0.879 & [73] \\
\hline $\begin{array}{l}\text { Uranyl coordination } \\
\text { polymer }\end{array}$ & NA & NA & NA & NA & NA & NA & 205 & NA & 0.991 & NA & NA & NA & [80] \\
\hline $\mathrm{ZnFe}_{2} \mathrm{O}_{4}$ nanocomposite & 3.38 & 0.05 & 0.9861 & 10.10 & 0.04 & 0.999 & 12.1 & 0.19 & 0.994 & 3.03 & 2.66 & 0.972 & [78] \\
\hline $\begin{array}{l}\text { Bentonite-titanium dioxide } \\
\text { composites }\end{array}$ & NA & NA & NA & NA & NA & NA & 0.25 & 1523 & 0.995 & 0.12 & 5.62 & 0.988 & [81] \\
\hline $\begin{array}{l}\text { Zinc oxide loaded activated } \\
\text { carbon }(\mathrm{ZnO}-\mathrm{AC})\end{array}$ & 76.37 & 0.05 & 0.876 & 120.5 & 0.02 & 0.999 & 128 & 6.50 & 0.997 & 88 & 7.35 & 0.735 & [5] \\
\hline
\end{tabular}

$\mathrm{q}_{\mathrm{m}}$ : Monolayer maximum adsorption capacity of RhB per unit mass of sorbent $\left(\mathrm{mg} \mathrm{g}^{-1}\right)$ and $\mathrm{K}_{\mathrm{L}}$ : Langmuir constant related to the binding energy of RhB sorption $\left(\mathrm{L} \mathrm{mg}^{-1}\right), \mathrm{R}_{\mathrm{L}}$ : indicates the dimensionless separation factor, $\mathrm{K}_{\mathrm{F}}$ : adsorption capacity of the sorbent $\left(\mathrm{L} \mathrm{g}^{-1}\right)$, $\mathrm{n}$ : gives an indication of how favorable the adsorption process in terms of surface heterogeneity and affinity for the adsorbate, qe: Equilibrium quantity of adsorbate per unit mass of the sorbent $\left(\mathrm{mg} \mathrm{g}^{-1}\right), \mathrm{K}_{1}$ : Firstorder kinetic model $\left(\min ^{-1}\right)$, $\mathrm{K}_{2}$ : Second-order kinetic model $\left(\mathrm{g}(\mathrm{mg} \mathrm{min})^{-1}\right)$, and $\mathrm{R}^{2}$ : Correlation factor and NA: Not achieved 
Table 6. Analytical features of experimental and thermodynamic parameters of adsorption RhB by different techniques during 2018

\begin{tabular}{|c|c|c|c|c|c|c|c|c|c|c|c|}
\hline \multirow[b]{2}{*}{ Adsorbents } & \multicolumn{7}{|c|}{ Experimental parameters } & \multicolumn{3}{|c|}{ Thermodynamics } & \multirow[b]{2}{*}{ Ref. } \\
\hline & $\mathrm{Q}_{\max }(\mathrm{mg} / \mathrm{g})$ & $\mathrm{pH}$ & $\begin{array}{c}\mathrm{T} \\
(\mathrm{K})\end{array}$ & $\begin{array}{c}\mathrm{C}^{\circ} \\
(\mathrm{mg} / \mathrm{L})\end{array}$ & $\begin{array}{c}\mathrm{T} \\
(\mathrm{min})\end{array}$ & $\begin{array}{c}\mathrm{AD} \\
(\mathrm{g} / \mathrm{L})\end{array}$ & Model & $\begin{array}{c}\Delta \mathrm{G}^{\circ} \\
(\mathrm{kJ} / \mathrm{mol})\end{array}$ & $\begin{array}{c}\Delta \mathrm{H}^{\circ} \\
(\mathrm{kJ} / \mathrm{mol})\end{array}$ & $\begin{array}{c}\Delta \mathrm{S}^{\circ} \\
(\mathrm{J} / \mathrm{mol} . \mathrm{K})\end{array}$ & \\
\hline Banana peel & 211.9 & 6 & 383 & 100 & 30 & 0.1 & $\begin{array}{c}\mathrm{F}-\mathrm{L} \\
\mathrm{K}_{1}-\mathrm{K}_{2}\end{array}$ & NP & NP & NP & [37] \\
\hline Cucumber peel & 179.9 & 6 & 383 & 100 & 30 & 0.1 & $\begin{array}{c}\mathrm{F}-\mathrm{L} \\
\mathrm{K}_{1}-\mathrm{K}_{2}\end{array}$ & NP & NP & NP & {$[37]$} \\
\hline Potato peel & 107.4 & 6 & 383 & 100 & 30 & 0.1 & $\begin{array}{c}\mathrm{F}-\mathrm{L} \\
\mathrm{K}_{1}-\mathrm{K}_{2}\end{array}$ & NP & NP & NP & {$[37]$} \\
\hline Banana peel powder & NP & 4 & $304-333$ & 100 & 60 & $0.04-0.5$ & L-F-T & NP & NP & $\mathrm{NP}$ & [48] \\
\hline Chlorella pyrenoidosa & 63.14 & 8 & 298 & 100 & 120 & 0.1 & $\begin{array}{c}\mathrm{L}-\mathrm{F}-\mathrm{K}_{1}-\mathrm{K}_{2}-\mathrm{E}- \\
\mathrm{Te}-\mathrm{S}\end{array}$ & NP & NP & NP & {$[13]$} \\
\hline Clay minerals & 24 & $2-12$ & 295 & NP & 20 & NP & $\mathrm{L}-\mathrm{K}_{2}$ & -14.6 & 3.7 & 0.06 & {$[7]$} \\
\hline Electrochemical decolorization & NP & 6.5 & 298 & 50 & 90 & NP & $K_{1}$ & NP & NP & NP & {$[45]$} \\
\hline Ability of $3 \mathrm{~A}$ zeolite in removal of $\mathrm{RhB}$ & NP & 9 & NP & 20 & 40 & 0.5 & NP & NP & NP & NP & [73] \\
\hline $\mathrm{Ag}_{3} \mathrm{PO} 4 / \mathrm{Bi}_{2} \mathrm{WO}_{6}$ nanocomposites & NP & 0.71 & 353 & NP & 30 & 2.5 & NP & NP & NP & NP & {$[35]$} \\
\hline Iron-doped mesoporous silica & NP & 3 & 308 & 10 & 180 & 1 & NP & NP & NP & NP & {$[44]$} \\
\hline Iron oxide/carbon nanocomposites & 93.35 & 6.5 & 298 & 100 & 60 & 1 & L-F, $\mathrm{K}_{1}-\mathrm{K}_{2}$ & NP & NP & NP & [28] \\
\hline
\end{tabular}

Table 7. Analytical features of isothermal and kinetic parameters of adsorption RhB by different techniques during 2018

\begin{tabular}{|c|c|c|c|c|c|c|c|c|c|c|c|c|c|}
\hline \multirow[b]{3}{*}{ Adsorbents } & \multicolumn{7}{|c|}{ Kinetic Parameters } & \multicolumn{5}{|c|}{ Isothermal Parameters } & \multirow[b]{3}{*}{ Ref. } \\
\hline & \multicolumn{3}{|c|}{ Pseudo-first order kinetic } & \multicolumn{4}{|c|}{ Pseudo-second order kinetic } & \multicolumn{2}{|c|}{ Langmuir } & \multicolumn{3}{|c|}{ Freundlich } & \\
\hline & $\begin{array}{c}\mathrm{q}_{\mathrm{e}} \\
(\mathrm{mg} / \mathrm{g})\end{array}$ & $\begin{array}{c}\mathrm{K}_{1} \\
\left(\min ^{-1}\right)\end{array}$ & $\mathrm{R}^{2}$ & $\begin{array}{c}\mathrm{q}_{\mathrm{e}} \\
(\mathrm{mg} / \mathrm{g})\end{array}$ & $\begin{array}{c}\mathrm{K}_{2} \\
\left(\mathrm{~g} \mathrm{mg}^{-1}\right. \\
\left.\min ^{-1}\right)\end{array}$ & $\mathrm{R}^{2}$ & $\begin{array}{c}\mathrm{q}_{\mathrm{m}} \\
(\mathrm{mg} / \mathrm{g})\end{array}$ & $\begin{array}{c}\mathrm{K}_{\mathrm{L}} \\
(\mathrm{L} / \mathrm{mg})\end{array}$ & $\mathrm{R}^{2}$ & $\mathrm{~K}_{\mathrm{F}}$ & $\mathrm{n}$ & $\mathrm{R}^{2}$ & \\
\hline Banana peel & 97 & 23.58 & 0.9919 & 99.9 & 5.14 & 0.9992 & 211.9 & $0.288-0.013$ & 0.999 & 35.76 & 0.4752 & 0.836 & [37] \\
\hline Cucumber peel & 78.5 & 24.85 & 0.9009 & 76.5 & 21.79 & 0.9998 & 107.4 & $0.459-0.027$ & 0.999 & 5.44 & 0.7928 & 0.80 & [37] \\
\hline Potato peel & 84 & 49.31 & 0.9944 & 85.6 & 16.97 & 0.9995 & 179.9 & $0.172-0.053$ & 0.993 & 14.94 & 0.4338 & 0.853 & [37] \\
\hline Banana peel powder & NP & NP & NP & NP & NP & NP & 1.6572 & 0.0658 & 0.9740 & $\mathrm{NP}$ & $\mathrm{NP}$ & NP & [48] \\
\hline Chlorella pyrenoidosa & 24.75 & 0.284 & 0.9799 & 25.54 & NP & NP & NP & 0.0070 & 0.9905 & NP & NP & NP & [13] \\
\hline $\begin{array}{l}\text { Iron oxide/carbon } \\
\text { nanocomposites }\end{array}$ & 72.79 & 23.21 & 0.990 & 102.27 & 0.65 & 0.9985 & 131.80 & 0.19 & 0.9398 & 34.41 & 3.06 & 0.8454 & [28] \\
\hline $\begin{array}{l}\text { Direct carbonization of } \\
\text { Zn/Co zeolitic imidazolate }\end{array}$ & 89.8 & 0.0963 & 0.8935 & 101.8 & $9.1 \times 10^{-1}$ & 0.9991 & 119.9 & 0.18 & 0.9991 & 61.1 & 7.50 & 0.9458 & [32] \\
\hline $\begin{array}{l}\text { Polyamide grafted heavy } \\
\text { metals }\end{array}$ & 4.1 & 0.033 & 0.8979 & 1.5 & 1.157 & 0.9968 & 19.9 & 1.04 & 0.9946 & 2.88 & 2.12 & 0.9873 & [19] \\
\hline $\begin{array}{l}\text { Novel biopolymer } \\
\text { silicalite-1 }\end{array}$ & 2.2 & 0.012 & 0.97 & 4.5 & 0.034 & 0.99 & 45 & 0.034 & 0.97 & 3.4 & 1.61 & 0.99 & [10] \\
\hline $\begin{array}{l}\text { Microporous nanohybrids } \\
\text { of carbon xerogels }\end{array}$ & NP & NP & NP & NP & $\mathrm{NP}$ & NP & 50 & 0.008 & 0.995 & 8.50 & 2.43 & 0.946 & [87] \\
\hline
\end{tabular}

$\mathrm{q}_{\mathrm{m}}$ : Monolayer maximum adsorption capacity of RhB per unit mass of sorbent $\left(\mathrm{mg} \mathrm{g}^{-1}\right)$ and $\mathrm{K}_{\mathrm{L}}$ : Langmuir constant related to the binding energy of RhB sorption $\left(\mathrm{Lmg}^{-1}\right), \mathrm{R}_{\mathrm{L}}$ : indicates the dimensionless separation factor, $\mathrm{K}_{\mathrm{F}}$ adsorption capacity of the sorbent $\left(\mathrm{L} \mathrm{g}^{-1}\right)$, n: gives an indication of how favorable the adsorption process in terms of surface heterogeneity and affinity for the adsorbate, qe: Equilibrium quantity of adsorbate per unit mass of the sorbent ( $\left.\mathrm{mg} \mathrm{g}^{-1}\right)$, $\mathrm{K}_{1}$ : First-order kinetic model $\left(\mathrm{min}^{-1}\right), \mathrm{K}_{2}$ : Second-order kinetic model $\left(\mathrm{g}(\mathrm{mg} \mathrm{min})^{-1}\right)$, and $\mathrm{R}^{2}$ : Correlation factor and NA: Not achieved

Table 8. Analytical features of experimental and thermodynamic parameters of adsorption RhB by different techniques during 2019

\begin{tabular}{|c|c|c|c|c|c|c|c|c|c|c|c|}
\hline \multirow[b]{2}{*}{ Adsorbent } & \multicolumn{6}{|c|}{ Experimental Parameters } & \multicolumn{4}{|c|}{ Thermodynamic } & \multirow[b]{2}{*}{ Ref. } \\
\hline & $\begin{array}{l}\mathrm{Q}_{\max } \\
(\mathrm{mg} / \mathrm{g})\end{array}$ & $\mathrm{pH}$ & $\mathrm{T}\left(\mathrm{C}^{\circ}\right)$ & $\mathrm{C}^{o}(\mathrm{mg} / \mathrm{L})$ & $\begin{array}{l}\mathrm{T} \\
(\mathrm{min})\end{array}$ & $\begin{array}{l}\mathrm{AD} \\
(\mathrm{g} / \mathrm{L})\end{array}$ & Model & $\begin{array}{l}\Delta \mathrm{G}^{\circ} \\
(\mathrm{kJ} / \mathrm{mol})\end{array}$ & $\begin{array}{l}\Delta \mathrm{H}^{\circ} \\
(\mathrm{kJ} / \mathrm{mol})\end{array}$ & $\begin{array}{l}\Delta S^{\circ} \\
(\mathrm{J} / \mathrm{mol} \mathrm{K})\end{array}$ & \\
\hline Acid activated locust bean & 454.5 & 6.8 & 30 & 1000 & 120 & 0.1 & $\mathrm{~L}, \mathrm{~F}, \mathrm{~K}_{1}$ & -26.35 & 58.779 & 208.95 & {$[88]$} \\
\hline Hybrid ion- exchanger & 1.23 & $2.9>$ & 50 & 10 & 180 & 5 & $\mathrm{~L}, \mathrm{~F}, \mathrm{~K}_{2}$ & 1.69 & NA & NA & [18] \\
\hline
\end{tabular}


Table 8. Analytical features of experimental and thermodynamic parameters of adsorption RhB by different techniques during 2019 (Continued)

\begin{tabular}{|c|c|c|c|c|c|c|c|c|c|c|c|}
\hline \multirow[b]{2}{*}{ Adsorbent } & \multicolumn{6}{|c|}{ Experimental Parameters } & \multicolumn{4}{|c|}{ Thermodynamic } & \multirow[b]{2}{*}{ Ref. } \\
\hline & $\begin{array}{l}\mathrm{Q}_{\max } \\
(\mathrm{mg} / \mathrm{g})\end{array}$ & $\mathrm{pH}$ & $\mathrm{T}\left(\mathrm{C}^{\circ}\right)$ & $\mathrm{C}^{\circ}(\mathrm{mg} / \mathrm{L})$ & $\begin{array}{l}\mathrm{T} \\
(\min )\end{array}$ & $\begin{array}{l}\mathrm{AD} \\
(\mathrm{g} / \mathrm{L})\end{array}$ & Model & $\begin{array}{l}\Delta \Delta \mathrm{G}^{\circ} \\
(\mathrm{kJ} / \mathrm{mol})\end{array}$ & $\begin{array}{l}\Delta \mathrm{H}^{\circ} \\
(\mathrm{kJ} / \mathrm{mol})\end{array}$ & $\begin{array}{l}\Delta \mathrm{S}^{\circ} \\
(\mathrm{J} / \mathrm{mol} \mathrm{K})\end{array}$ & \\
\hline MgO nanoparticles & 2462.5 & 7 & 25 & 10 & 60 & 0.04 & $\mathrm{~L}, \mathrm{~F}$ & -12.06 & 9.440 & 72.00 & [36] \\
\hline $\begin{array}{l}\text { Activated sugar-based } \\
\text { carbon (ASC) }\end{array}$ & 123.46 & $2-11$ & $15-45$ & 50 & 12 & 0.08 & $\mathrm{~L}, \mathrm{~F}, \mathrm{~K}_{2}$ & NA & NA & NA & {$[17]$} \\
\hline $\begin{array}{l}\text { Zeolitic imidazolate } \\
\text { frameworks (ZIF) }\end{array}$ & 85.0 & $10<$ & 30 & $20-200$ & 1440 & 2.1 & $\mathrm{~L}, \mathrm{~F}$ & NA & NA & NA & [41] \\
\hline $\begin{array}{l}\text { Organo-vermiculites } \\
\text { (organo-Vts) }\end{array}$ & 528 & 2 & 25 & $50-1000$ & 90 & 0.05 & $\mathrm{~L}, \mathrm{~F}$ & -20.8 & -5.21 & 52.79 & [89] \\
\hline
\end{tabular}

$\mathrm{Q}_{\max }$ : Maximum adsorption of $\mathrm{RhB}$ adsorbed per unit mass of adsorbent after equilibrium $\left(\mathrm{mg} \mathrm{g}^{-1}\right), \mathrm{T}\left({ }^{\circ} \mathrm{C}\right)$ : Temperature, Co: Initial Concentration ( $\left.\mathrm{mg} \mathrm{L}^{-1}\right), \mathrm{T}(\mathrm{min})$ : Equilibrium Contact Time, A.D: Adsorbent dosage $\left(\mathrm{g} \mathrm{L}^{-1}\right), \Delta \mathrm{G}^{\circ}$ : Standard Gibbs free energy $\left(\mathrm{kJ} \mathrm{mol}^{-1}\right), \Delta \mathrm{H}^{\circ}$ : Standard enthalpy $(\mathrm{kJ}$ $\left.\mathrm{mol}^{-1}\right), \Delta \mathrm{S}^{\circ}$ : Standard entropy $\left(\mathrm{J} \mathrm{mol}^{-1} \mathrm{~K}^{-1}\right)$, L: Langmuir isotherm model, F: Freundlich Isotherm model and DR: Dubinin-Radushkevich. NA: Not Achieved

Table 9. Analytical features of isothermal and kinetic parameters of adsorption RhB by different techniques during 2019

\begin{tabular}{|c|c|c|c|c|c|c|c|c|c|c|c|c|c|c|}
\hline \multirow{3}{*}{ Adsorbent } & \multicolumn{7}{|c|}{ Isothermal } & \multicolumn{6}{|c|}{ Kinetic parameter } & \multirow{3}{*}{ Ref. } \\
\hline & \multicolumn{4}{|c|}{ Langmuir } & \multicolumn{3}{|c|}{ Freundlich } & \multicolumn{3}{|c|}{ Pseudo-first order } & \multicolumn{3}{|c|}{ Pseudo-second order } & \\
\hline & $\begin{array}{c}\mathrm{q}_{\mathrm{m}} \\
(\mathrm{mg} / \mathrm{g})\end{array}$ & $\begin{array}{c}\mathrm{K}_{\mathrm{L}} \\
(\mathrm{L} / \mathrm{mg})\end{array}$ & $\mathrm{R}^{2}$ & $\mathrm{R}_{\mathrm{L}}$ & $\mathrm{K}_{\mathrm{F}}$ & $\mathrm{n}$ & $\mathrm{R}^{2}$ & $\begin{array}{c}\mathrm{K}_{1} \\
\left(\min ^{-1}\right)\end{array}$ & $\begin{array}{c}\mathrm{q}_{\mathrm{e}} \\
(\mathrm{mg} / \mathrm{g})\end{array}$ & $\mathrm{R}^{2}$ & $\mathrm{~K}_{2}$ & $\begin{array}{c}\mathrm{q}_{\mathrm{e}} \\
(\mathrm{mg} / \mathrm{g})\end{array}$ & $\mathrm{R}^{2}$ & \\
\hline $\begin{array}{l}\text { Acid activated locust } \\
\text { bean }\end{array}$ & 455 & 4.66 & 0.9991 & 0.6 & 80 & 0.4 & 0.9966 & 0.03 & 73 & 0.9865 & 0.1 & 909 & 0.9941 & {$[88]$} \\
\hline Hybrid ion- exchanger & 1.23 & 0.97 & 0.992 & 0 & 1.2 & 1.2 & 0.986 & 0.01 & 51 & 0.854 & 0.3 & 69.4 & 0.992 & [18] \\
\hline $\mathrm{MgO}$ nanoparticle & 2791 & 0.07 & 0.9991 & 0 & 18 & 1.2 & 0.9993 & 3.92 & 0.9 & 0.9823 & 0.2 & 95.4 & 0.9992 & [36] \\
\hline $\begin{array}{l}\text { Activated sugar-based } \\
\text { carbon (ASC) }\end{array}$ & 123 & 0.72 & 0.9796 & 0.2 & 50 & 2.7 & 0.6416 & 0.39 & 61 & 0.9679 & 0.7 & 71.9 & 0.9982 & {$[17]$} \\
\hline Zeolitic imidazolate & 85 & 0.01 & 0.9970 & NA & 0.9 & 3.9 & 0.8048 & 0.01 & 21 & 0.8377 & 0.2 & 73 & 0.9989 & [41] \\
\hline
\end{tabular}

qm: Monolayer maximum adsorption capacity of $\mathrm{RhB}$ per unit mass of sorbent $\left(\mathrm{mg} \mathrm{g}^{-1}\right)$ and $\mathrm{K}_{\mathrm{L}}$ : Langmuir constant related to the binding energy of RhB sorption $\left(\mathrm{L} \mathrm{mg}^{-1}\right), \mathrm{R}_{\mathrm{L}}$ : indicates the dimensionless separation factor, $\mathrm{K}_{\mathrm{F}}$ : adsorption capacity of the sorbent $\left(\mathrm{L} \mathrm{g}^{-1}\right)$, $\mathrm{n}$ : gives an indication of how favorable the adsorption process in terms of surface heterogeneity and affinity for the adsorbate, $\mathrm{q}_{\mathrm{e}}$ : Equilibrium quantity of adsorbate per unit mass of the sorbent $\left(\mathrm{mg} \mathrm{g}^{-1}\right), \mathrm{K}_{1}$ : First-order kinetic model $\left(\mathrm{min}^{-1}\right), \mathrm{K}_{2}$ : Second-order kinetic model $\left(\mathrm{g}(\mathrm{mg} \mathrm{min})^{-1}\right)$, and $\mathrm{R}^{2}$ : Correlation factor and NA: Not achieved

Table 10. Analytical features of experimental and thermodynamic parameters of adsorption RhB by different techniques during 2020

\begin{tabular}{|c|c|c|c|c|c|c|c|c|c|c|c|}
\hline \multirow[b]{2}{*}{ Adsorbent } & \multicolumn{7}{|c|}{ Experimental Parameters } & \multicolumn{3}{|c|}{ Thermodynamic } & \multirow[b]{2}{*}{ Ref. } \\
\hline & $\begin{array}{c}\mathrm{Q}_{\max } \\
(\mathrm{mg} / \mathrm{g}) \\
\end{array}$ & $\mathrm{pH}$ & $\begin{array}{c}\mathrm{T} \\
\left({ }^{\circ} \mathrm{C}\right) \\
\end{array}$ & $\begin{array}{c}\mathrm{C}^{\circ} \\
(\mathrm{mg} / \mathrm{L}) \\
\end{array}$ & $\begin{array}{c}\mathrm{T} \\
(\mathrm{min}) \\
\end{array}$ & $\begin{array}{l}\mathrm{AD} \\
(\mathrm{g} / \mathrm{L}) \\
\end{array}$ & Model & $\begin{array}{c}\Delta \mathrm{G}^{\circ} \\
(\mathrm{kJ} / \mathrm{mol})\end{array}$ & $\begin{array}{c}\Delta \mathrm{H}^{\circ} \\
(\mathrm{kJ} / \mathrm{mol})\end{array}$ & $\begin{array}{c}\Delta S^{\circ} \\
(\mathrm{J} / \mathrm{mol} \mathrm{K}) \\
\end{array}$ & \\
\hline Cassava slag biochar (HCS) & 105.3 & 4.99 & 35 & 500 & $1-720$ & 0.1 & $\mathrm{~L}, \mathrm{~F}, \mathrm{DR}, \mathrm{T}$ & -8.116 & 222.5 & 1.192 & {$[70]$} \\
\hline Dowex 5WX8 Resin & 43.47 & 2.8 & 25 & 50 & 12 & 0.08 & $\mathrm{~L}$ and $\mathrm{F}$ & NA & NA & NA & [83] \\
\hline $\begin{array}{l}\text { Three-dimensional layered double } \\
\text { hydroxide }\end{array}$ & 49.6 & NA & 150 & 60 & 30 & 0.05 & $\mathrm{~L}$ and $\mathrm{F}$ & NA & NA & NA & {$[90]$} \\
\hline $\mathrm{SiO}_{2} / \mathrm{TiO}_{2}$ composite powders & 625 & 3.2 & 25 & $75-300$ & 8.6 & NA & $\mathrm{L}$ and $\mathrm{F}$ & NA & -14.75 & -40.43 & [30] \\
\hline $\mathrm{CdO}$ nanomaterial & NA & 6 & 35 & $10-100$ & 80 & 0.1 & $\mathrm{~L}, \mathrm{~F}, \mathrm{~T}$ & -79.55 & NA & NA & [91] \\
\hline $\begin{array}{l}\text { Ni-graphene hybrid composites } \\
\text { (NGC25b) }\end{array}$ & 963 & NA & 70 & 120 & 15 & NA & $\mathrm{L}$ and $\mathrm{F}$ & NA & NA & NA & {$[74]$} \\
\hline Grass-Waste & 54 & 6.6 & 35 & 100 & 400 & 0.1 & $\mathrm{~L}$ and $\mathrm{F}$ & -0.23 & 20.28 & 0.07 & [49] \\
\hline
\end{tabular}

$\mathrm{Q}_{\max }$ : Maximum adsorption of RhB adsorbed per unit mass of adsorbent after equilibrium $\left(\mathrm{mg} \mathrm{g}^{-1}\right), \mathrm{T}\left({ }^{\circ} \mathrm{C}\right)$ : Temperature, Co: Initial Concentration $\left(\mathrm{mg} \mathrm{L}^{-1}\right)$,

$\mathrm{T}(\mathrm{min})$ : Equilibrium Contact Time, A.D: Adsorbent dosage $\left(\mathrm{g} \mathrm{L}^{-1}\right), \Delta \mathrm{G}^{\circ}$ : Standard Gibbs free energy $\left(\mathrm{kJ} \mathrm{mol}^{-1}\right), \Delta \mathrm{H}^{\circ}$ : Standard enthalpy $\left(\mathrm{kJ}\right.$ mol $\left.{ }^{-1}\right), \Delta S^{\circ}$ :

Standard entropy $\left(\mathrm{J} \mathrm{mol}^{-1} \mathrm{~K}^{-1}\right)$, L: Langmuir isotherm model, F: Freundlich Isotherm model and DR: Dubinin-Radushkevich. NA: Not Achieved 
Table 11. Analytical features of isothermal and kinetic parameters of RhB adsorption by different techniques during 2020

\begin{tabular}{|c|c|c|c|c|c|c|c|c|c|c|c|c|c|c|}
\hline \multirow{3}{*}{ Adsorbent } & \multicolumn{7}{|c|}{ Isothermal } & \multicolumn{6}{|c|}{ Kinetic parameter } & \multirow{3}{*}{ Ref. } \\
\hline & \multicolumn{4}{|c|}{ Langmuir } & \multicolumn{3}{|c|}{ Freundlich } & \multicolumn{3}{|c|}{ Pseudo-first order } & \multicolumn{3}{|c|}{ Pseudo-second order } & \\
\hline & $\begin{array}{l}\mathrm{q}_{\mathrm{m}} \\
(\mathrm{mg} / \mathrm{g})\end{array}$ & $\begin{array}{l}\mathrm{K}_{\mathrm{L}} \\
(\mathrm{L} / \mathrm{mg})\end{array}$ & $\mathrm{R}^{2}$ & $\mathrm{R}_{\mathrm{L}}$ & $\mathrm{K}_{\mathrm{F}}$ & $\mathrm{n}$ & $\mathrm{R}^{2}$ & $\begin{array}{l}\mathrm{K}_{1} \\
\left(\min ^{-1}\right)\end{array}$ & $\begin{array}{l}\mathrm{q}_{\mathrm{e}} \\
(\mathrm{mg} / \mathrm{g})\end{array}$ & $\mathrm{R}^{2}$ & $\begin{array}{l}\mathrm{K}_{2} \\
(\mathrm{~g} / \mathrm{min} \mathrm{mg})\end{array}$ & $\begin{array}{l}\mathrm{q}_{\mathrm{e}} \\
(\mathrm{mg} / \mathrm{g})\end{array}$ & $\mathrm{R}^{2}$ & \\
\hline Cassava slag biochar (HCS) & 105.3 & 0.51 & 0.973 & NA & 12.9 & 2.3 & 0.989 & 0.038 & 5.09 & 0.923 & 0.01 & 24.1 & 0.99 & {$[70]$} \\
\hline Dowex 5WX8 Resin & 43.4 & 0.01 & 0.990 & 0.2 & NA & $<1$ & 0.087 & NA & NA & NA & NA & NA & NA & {$[83]$} \\
\hline $\begin{array}{l}\text { Three-dimensional layered } \\
\text { double hydroxide }\end{array}$ & 52.63 & 0.3 & 0.930 & NA & 18.6 & 3.8 & 0.982 & 0.7 & 25.9 & 0.9872 & 0.08 & 50.8 & 0.999 & {$[90]$} \\
\hline $\mathrm{SiO}_{2} / \mathrm{TiO}_{2}$ composite powders & NA & NA & NA & NA & NA & NA & NA & NA & NA & NA & NA & NA & NA & {$[30]$} \\
\hline $\mathrm{CdO}$ nanomaterial & 361.01 & 0.68 & 0.994 & NA & 1.63 & 0.8 & 0.989 & 0.006 & 4.008 & 0.906 & 0.01 & 3.5 & 0.9907 & [91] \\
\hline $\begin{array}{l}\text { Ni-graphene hybrid } \\
\text { composites (NGC25b) }\end{array}$ & 963.04 & NA & 0.957 & NA & NA & NA & NA & NA & NA & 0.9989 & NA & NA & NA & {$[74]$} \\
\hline
\end{tabular}

$\mathrm{q}_{\mathrm{m}}$ : Monolayer maximum adsorption capacity of $\mathrm{RhB}$ per unit mass of sorbent $\left(\mathrm{mg} \mathrm{g}^{-1}\right.$ ) and $\mathrm{K}_{\mathrm{L}}$ : Langmuir constant related to the binding energy of RhB sorption $\left(\mathrm{L} \mathrm{mg}^{-1}\right), \mathrm{R}_{\mathrm{L}}$ : indicates the dimensionless separation factor, $\mathrm{K}_{\mathrm{F}}$ : adsorption capacity of the sorbent $\left(\mathrm{L} \mathrm{g}^{-1}\right)$, $\mathrm{n}$ : gives an indication of how favorable the adsorption process in terms of surface heterogeneity and affinity for the adsorbate, $\mathrm{q}_{\mathrm{e}}$ : Equilibrium quantity of adsorbate per unit mass of the sorbent ( $\mathrm{mg}^{-1}$ ), $\mathrm{K}_{1}$ : First-order kinetic model $\left(\mathrm{min}^{-1}\right), \mathrm{K}_{2}$ : Second-order kinetic model $\left(\mathrm{g}(\mathrm{mg} \mathrm{min})^{-1}\right)$, and $\mathrm{R}^{2}$ : Correlation factor and NA: Not achieved

\section{Modern Techniques for the Removal of RhB Dye}

In general, most of the toxic material composition in the textile industry effluents and the challenging conditions of breaking down the bonding of few dyes used in textiles, usage of conventional techniques needs a flavor of modern technological support. The modern enabling techniques for water quality monitoring utilize smart sensors interfaced with modern controllers and interconnected using wireless standards to monitor water quality. Several examples of widely used sensors are smart [92], optical [93], and wireless [51] sensors.

\section{- CONCLUSION}

This review covers recent information and future applications of RhB dye adsorption. The results showed that kinetic data of adsorption of $\mathrm{RhB}$ dye usually follow the pseudo-first-order and pseudo-second-order kinetic models. It has also been revealed that Langmuir and Freundlich adsorption isotherm models are frequently used to evaluate the adsorption capacity of the adsorbents. Furthermore, thermodynamic examination showed that $\mathrm{RhB}$ adsorption was endothermic and unconstrained in nature. Therefore, both photocatalytic degradation and adsorption methods offer good potential to remove $\mathrm{RhB}$ dye from industrial effluents. The present review indicated that the adsorption technique using natural adsorbents such as different fruit peels and rice husk was beneficial and cost-effective for better removal of RhB dye. The work is in progress to evaluate the possibility of using other modified waste biomass for industrial pollution control.

\section{- REFERENCES}

[1] Ali, I., Gupta, V.K., and Aboul-Enein, H.Y., 2005, Metal ion speciation and capillary electrophoresis: application in the new millennium, Electrophoresis, 26 (21), 3988-4002.

[2] Basheer, A.A., 2018, Chemical chiral pollution: Impact on the society and science and need of the regulations in the $21^{\text {st }}$ century, Chirality, 30 (4), 402-406.

[3] Basheer, A.A., and Ali, I., 2018, Stereoselective uptake and degradation of $( \pm)-o, p$-DDD pesticide stereomers in water-sediment system, Chirality, 30 (9), 1088-1095.

[4] Basheer, A.A., 2018, New generation nanoadsorbents for the removal of emerging contaminants in water, J. Mol. Liq., 261, 583-593.

[5] Li, Y., Yan, X., Hu, X., Feng, R., and Zhou, M., 2019, Trace pyrolyzed ZIF-67 loaded activated carbon pellets for enhanced adsorption and catalytic degradation of Rhodamine B in water, Chem. Eng. J., 375, 122003.

[6] Nekouei Marnani, N., and Shahbazi, A., 2019, A novel environmental-friendly nanobiocomposite synthesis by EDTA and chitosan functionalized magnetic graphene oxide for high removal of 
Rhodamine B: Adsorption mechanism and separation property, Chemosphere, 218, 715-725.

[7] Li, Z., Potter, N., Rasmussen, J., Weng, J., and Lv, G., 2018, Removal of rhodamine 6G with different types of clay minerals, Chemosphere, 202, 127-135.

[8] Inyinbor, A.A., Adekola, F.A., and Olatunji, G.A., 2016, Kinetics, isotherms and thermodynamic modeling of liquid phase adsorption of Rhodamine B dye onto Raphia hookerie fruit epicarp, Water Resour. Ind., 15, 14-27.

[9] Tao, P., Xu, Y., Song, C., Yin, Y., Yang, Z., Wen, S., Wang, S., Liu, H., Li, S., Li, C., Wang, T., and Shao, M., 2017, A novel strategy for the removal of Rhodamine B (RhB) dye from wastewater by coalbased carbon membranes coupled with the electric field, Sep. Purif. Technol., 179, 175-183.

[10] Sabarish, R., and Unnikrishnan, G., 2018, Novel biopolymer templated hierarchical silicalite- 1 as an adsorbent for the removal of Rhodamine B, J. Mol. Liq., 272, 919-929.

[11] Ghasemi, E., and Kaykhaii, M., 2016, Application of Micro-cloud point extraction for spectrophotometric determination of Malachite green, Crystal violet and Rhodamine B in aqueous samples, Spectrochim. Acta, Part A, 164, 93-97.

[12] Bethi, B., Manasa, V., Srinija, K., and Sonawane, S.H., 2018, Intensification of Rhodamine-B dye removal using hydrodynamic cavitation coupled with hydrogel adsorption, Chem. Eng. Process., 134, 51-57.

[13] da Rosa, A.L.D., Carissimi, E., Dotto, G.L., Sander, H., and Feris, L.A., 2018, Biosorption of Rhodamine $B$ dye from dyeing stones effluents using the green microalgae Chlorella pyrenoidosa, J. Cleaner Prod., 198, 1302-1310.

[14] Yu, Y., Wang, C., Luo, L., Wang, J., and Meng, J., 2018, An environment-friendly route to synthesize pyramid-like g- $\mathrm{C}_{3} \mathrm{~N}_{4}$ arrays for efficient degradation of Rhodamine B under visible-light irradiation, Chem. Eng. J., 334, 1869-1877.

[15] Pascariu, P., Airinei, A., Olaru, N., Olaru, L., and Nica, V., 2016, Photocatalytic degradation of Rhodamine $\mathrm{B}$ dye using $\mathrm{ZnO}-\mathrm{SnO}_{2}$ electrospun ceramic nanofibers, Ceram. Int., 42 (6), 6775-6781.
[16] Patil, S.P., Bethi, B., Sonawane, G.H., Shrivastava, V.S., and Sonawane, S., 2016, Efficient adsorption and photocatalytic degradation of Rhodamine $\mathrm{B}$ dye over $\mathrm{Bi}_{2} \mathrm{O}_{3}$-bentonite nanocomposites: $\mathrm{A}$ kinetic study, J. Ind. Eng. Chem., 34, 356-363.

[17] Xiao, W., Garba, Z.N., Sun, S., Lawan, I., Wang, L., Lin, M., and Yuan, Z., 2020, Preparation and evaluation of an effective activated carbon from white sugar for the adsorption of Rhodamine B dye, J. Cleaner Prod., 253, 119989.

[18] Saruchi, and Kumar, V., 2019, Adsorption kinetics and isotherms for the removal of Rhodamine $B$ dye and $\mathrm{Pb}^{+2}$ ions from aqueous solutions by a hybrid ion-exchanger, Arabian J. Chem., 12 (3), 316-329.

[19] Saleh, T.A., and Ali, I., 2018, Synthesis of polyamide grafted carbon microspheres for removal of Rhodamine B dye and heavy metals, J. Environ. Chem. Eng., 6 (4), 5361-5368.

[20] Chen, J., and Zhu, X., 2016, Magnetic solid phase extraction using ionic liquid-coated core-shell magnetic nanoparticles followed by highperformance liquid chromatography for determination of Rhodamine B in food samples, Food Chem., 200, 10-15.

[21] Ali, I., Burakov, A.E., Melezhik, A.V., Babkin, A.V, Burakova, I.V, Neskomornaya, E.A., Galunin, E.V., Tkachev, A.G., and Kuznetsov, D.V., 2019, Removal of copper(II) and zinc(II) ions in water on a newly synthesized polyhydroquinone/graphene nanocomposite material: kinetics, thermodynamics and mechanism, ChemistrySelect, 4 (43), 1270812718.

[22] Ali, I., Alharbi, O.M.L., Alothman, Z.A., AlMohaimeed, A.M., and Alwarthan, A., 2019, Modeling of fenuron pesticide adsorption on CNTs for mechanistic insight and removal in water, Environ. Res., 170, 389-397.

[23] Burakova, E.A., Dyachkova, T.P., Rukhov, A.V, Tugolukov, E.N., Galunin, E.V., Tkachev, A.G., Basheer, A.A., and Ali, I., 2018, Novel and economic method of carbon nanotubes synthesis on a nickel magnesium oxide catalyst using microwave radiation, J. Mol. Liq., 253, 340-346. 
[24] Ali, I., 2018, Microwave assisted economic synthesis of multi walled carbon nanotubes for arsenic species removal in water: Batch and column operations, $J$. Mol. Liq., 271, 677-685.

[25] Ali, I., and Aboul-Enein, H.Y., 2002, Speciation of metal ions by capillary electrophoresis, Crit. Rev. Anal. Chem., 32 (4), 337-350.

[26] Ali, I., Alharbi, O.M.L., Alothman, Z.A., and Alwarthan, A., 2018, Facile and eco-friendly synthesis of functionalized iron nanoparticles for cyanazine removal in water, Colloids Surf., B, 171, 606-613.

[27] Tian, J., Olajuyin, A.M., Mu, T., Yang, M., and Xing, J., 2016, Efficient degradation of rhodamine B using modified graphite felt gas diffusion electrode by electro-Fenton process, Environ. Sci. Pollut. Res., 23 (12), 11574-11583.

[28] Ianoş, R., Păcurariu, C., Muntean, S.G., Muntean, E., Nistor, M.A., and Nižňanský, D., 2018, Combustion synthesis of iron oxide/carbon nanocomposites, efficient adsorbents for anionic and cationic dyes removal from wastewaters, J. Alloys Compd., 741, 1235-1246.

[29] Tariq, M., Muhammad, M., Khan, J., Raziq, A., Uddin, M.K., Niaz, A., Ahmed, S.S., and Rahim, A., 2020, Removal of Rhodamine B dye from aqueous solutions using photo-Fenton processes and novel Ni-Cu@MWCNTs photocatalyst, J. Mol. Liq., 312, 113399.

[30] Wang, D., Hou, P., Stephan, D., Huang, S., Zhang, L., Yang, P., and Cheng, X., 2020, $\mathrm{SiO}_{2} / \mathrm{TiO}_{2}$ composite powders deposited on cement-based materials: Rhodamine B removal and the bonding mechanism, Constr. Build. Mater., 241, 118124.

[31] Kumar, V., Singh, M., Behera, K., and Pandey, S., 2020, Ionic liquid induced removal of Rhodamine B from water, J. Mol. Liq., 319, 114195.

[32] Zhang, J., Yan, X., Hu, X., Feng, R., and Zhou, M., 2018, Direct carbonization of $\mathrm{Zn} / \mathrm{Co}$ zeolitic imidazolate frameworks for efficient adsorption of Rhodamine B, Chem. Eng. J., 347, 640-647.

[33] Oyekanmi, A.A., Ahmad, A., Hossain, K., and Rafatullah, M., 2019, Statistical optimization for adsorption of Rhodamine B dye from aqueous solutions, J. Mol. Liq., 281, 48-58.

[34] Sundararajan, M., and Kennedy, L.J., 2017, Photocatalytic removal of Rhodamine $\mathrm{B}$ under irradiation of visible light using $\mathrm{Co}_{1-\mathrm{x}} \mathrm{CuxFe}_{2} \mathrm{O}_{4}(0 \leq$ $\mathrm{x} \leq 0.5$ ) nanoparticles, J. Environ. Chem. Eng., 5 (4), 4075-4092.

[35] Jonjana, S., Phuruangrat, A., Thongtem, T., Kuntalue, B., and Thongtem, S., 2018, Decolorization of Rhodamine B photocatalyzed by $\mathrm{Ag}_{3} \mathrm{PO}_{4} / \mathrm{Bi}_{2} \mathrm{WO}_{6}$ nanocomposites under visible radiation, Mater. Lett., 218, 146-149.

[36] Rahdar, S., Rahdar, A., Zafar, M.N., Shafqat, S.S., and Ahmadi, S., 2019, Synthesis and characterization of $\mathrm{MgO}$ supported $\mathrm{Fe}-\mathrm{Co}-\mathrm{Mn}$ nanoparticles with exceptionally high adsorption capacity for Rhodamine B dye, J. Mater. Res. Technol., 8 (5), 3800-3810.

[37] Stavrinou, A., Aggelopoulos, C.A., and Tsakiroglou, C.D., 2018, Exploring the adsorption mechanisms of cationic and anionic dyes onto agricultural waste peels of banana, cucumber and potato: Adsorption kinetics and equilibrium isotherms as a tool, $J$. Environ. Chem. Eng., 6 (6), 6958-6970.

[38] Al-Shaalan, N.H., Ali, I., Alothman, Z.A., AlWahaibi, L.H., and Alabdulmonem, H., 2019, High performance removal and simulation studies of diuron pesticide in water on MWCNTs, J. Mol. Liq., 289, 111039.

[39] Ali, I., Alharbi, O.M.L., Al-Othman, Z.A., Alwarthan, A., and Al-Mohaimeed, A.M., 2019, Preparation of a carboxymethylcellulose-iron composite for uptake of atorvastatin in water, Int. J. Biol. Macromol., 132, 244-253.

[40] Ali, I., Alharbi, O.M.L., Al-Othman, Z.A., and Badjah, A.Y., 2018, Kinetics, thermodynamics, and modeling of amido black dye photodegradation in water using $\mathrm{Co} / \mathrm{TiO}_{2}$ nanoparticles, Photochem. Photobiol., 94 (5), 935-941.

[41] Zhang, J., Hu, X., Yan, X., Feng, R., Zhou, M., and Xue, J., 2019, Enhanced adsorption of Rhodamine $B$ by magnetic nitrogen-doped porous carbon 
prepared from bimetallic ZIFs, Colloids Surf., A, 575, 10-17.

[42] Waheed, A., Mansha, M., Kazi, I.W., and Ullah, N., 2019, Synthesis of a novel 3,5-diacrylamidobenzoic acid based hyper-cross-linked resin for the efficient adsorption of Congo Red and Rhodamine B, J. Hazard. Mater., 369, 528-538.

[43] Yao, H., Wang, X., Gao, J., Gao, C., Zhao, R., Zhai, X., Wu, Y., Hao, C., Yang, J., Mei, S., and Qiu, H., 2019, Hydrothermal synthesis of flower-like $\mathrm{Cu}_{2} \mathrm{MoS}_{4} / \mathrm{g}$ $\mathrm{C}_{3} \mathrm{~N}_{4}$ composite and its adsorption performances for Rhodamine B, Mater. Chem. Phys., 223, 648-658.

[44] Jinisha, R., Gandhimathi, R., Ramesh, S.T., Nidheesh, P.V., and Velmathi, S., 2018, Removal of Rhodamine B dye from aqueous solution by electro-Fenton process using iron-doped mesoporous silica as a heterogeneous catalyst, Chemosphere, 200, 446-454.

[45] Baddouh, A., Bessegato, G.G., Rguiti, M.M., El Ibrahimi, B., Bazzi, L., Hilali, M., and Zanoni, M.V.B., 2018, Electrochemical decolorization of Rhodamine B dye: Influence of anode material, chloride concentration and current density, $J$. Environ. Chem. Eng., 6 (2), 2041-2047.

[46] Li, D., Li, J., and Tang, J., 2016, Mercury oxide as an efficient photocatalyst for degradation of Rhodamine B dye under visible-light irradiation, Solid State Sci., 61 (3), 201-206.

[47] Belachew, N., Rama Devi, D., and Basavaiah, K., 2017, Green synthesis and characterisation of LSerine capped magnetite nanoparticles for removal of Rhodamine B from contaminated water, J. Exp. Nanosci., 12 (1), 114-128.

[48] Singh, S., Parveen, N., and Gupta, H., 2018, Adsorptive decontamination of Rhodamine-B from water using banana peel powder: A biosorbent, Environ. Technol. Innovation, 12, 189-195.

[49] Zahir, A., Aslam, Z., Aslam, U., Abdullah, A., Ali, R., and Bello, M.M., 2020, Paspalum notatum grasswaste-based adsorbent for Rhodamine B removal from polluted water, Chem. Biochem. Eng. Q., 34 (2), 93-104.

[50] Berradi, M., Hsissou, R., Khudhair, M., Assouag, M., Cherkaoui, O., El Bachiri, A., and El Harfi, A., 2019,
Textile finishing dyes and their impact on aquatic environs, Heliyon, 5 (11), e02711.

[51] Imam, S., and Babamale, H., 2020, A short review on the removal of Rhodamine $\mathrm{B}$ dye using agricultural waste-based adsorbents, Asian J. Chem. Sci., 7 (1), 25-37.

[52] Shahzadi, A., Nosheen, S., Kiran, S., Riaz, S., Mughal, T.A., and Shahid, L., 2020, Plant waste utilization as ecofriendly sorbents for removal of reactive dyes from wastewater, Pak. J. Sci., 72 (2), 119.

[53] Alwared, A.I., Al-Musawi, T.J., Muhaisn, L.F., and Mohammed, A.A., 2020, The biosorption of reactive red dye onto orange peel waste: A study on the isotherm and kinetic processes and sensitivity analysis using the artificial neural network approach, Environ. Sci. Pollut. Res., 28 (3), 28482859.

[54] Stavrinou, A., Aggelopoulos, C.A., and Tsakiroglou, C.D., 2020, A methodology to estimate the sorption parameters from batch and column tests: The case study of methylene blue sorption onto banana peels, Processes, 8 (11), 1467.

[55] Nayak, A.K., and Pal, A., 2020, Statistical modeling and performance evaluation of biosorptive removal of Nile blue A by lignocellulosic agricultural waste under the application of high-strength dye concentrations, J. Environ. Chem. Eng., 8 (2), 103677.

[56] Saigl, Z.M., and Ahmed, A.M., 2021, Separation of Rhodamine B dye from aqueous media using natural pomegranate peels, Indones. J. Chem., 21 (1), 212-224.

[57] Lim, L.B.L., Priyantha, N., Fang, X.Y., and Mohamad Zaidi, N.A.H., 2017, Artocarpusodoratissimus peel as a potential adsorbent in environmental remediation to remove toxic Rhodamine B dye, J. Mater. Environ. Sci., 8 (2), 494-502.

[58] Shen, K., and Gondal, M.A., 2017, Removal of hazardous Rhodamine dye from water by adsorption onto exhausted coffee ground, J. Saudi Chem. Soc., 21 (Suppl. 1), S120-S127. 
[59] Dahri, M.K., Kooh, M.R.R., and Lim, L.B.L., 2016, Remediation of Rhodamine $B$ dye from aqueous solution using Casuarina equisetifolia cone powder as a low-cost adsorbent, Adv. Phys. Chem., 2016, 9497378.

[60] Garba, Z.N., and Rahim, A.A., 2016, Evaluation of optimal activated carbon from an agricultural waste for the removal of para-chlorophenol and 2,4dichlorophenol, Process Saf. Environ. Prot., 102, 5463.

[61] Al-Saadi, A.A., Saleh, T.A., and Gupta, V.K., 2013, Spectroscopic and computational evaluation of cadmium adsorption using activated carbon produced from rubber tires, J. Mol. Liq., 188, 136-142.

[62] Nasrullah, A., Saad, B., Bhat, A.H., Khan, A.S., Danish, M., Isa, M.H., and Naeem, A., 2019, Mangosteen peel waste as a sustainable precursor for high surface area mesoporous activated carbon: Characterization and application for methylene blue removal, J. Cleaner Prod., 211, 1190-1200.

[63] Senthilkumar, T., Chattopadhyay, S.K., and Miranda, L.R., 2017, Optimization of activated carbon preparation from pomegranate peel (Punica granatum peel) using RSM, Chem. Eng. Commun., 204 (2), 238-248.

[64] Xiao, W., Garba, Z.N., Sun, S., Lawan, I., Wang, L., Lin, M., and Yuan, Z., 2020, Preparation and evaluation of an effective activated carbon from white sugar for the adsorption of Rhodamine B dye, J. Cleaner Prod., 253, 119989.

[65] Alcântara, R.R., Muniz, R.O.R., and Fungaro, D.A., 2016, Full factorial experimental design analysis of Rhodamine B removal from water using organozeolite from coal bottom ash, Int. J. Energy Environ., 7 (5), 357-374.

[66] Dai, L., Zhu, W., He, L., Tan, F., Zhu, N., Zhou, Q., He, M., and Hu, G., 2018, Calcium-rich biochar from crab shell: An unexpected super adsorbent for dye removal, Bioresour. Technol., 267, 510-516.

[67] Sewu, D.D., Boakye, P., and Woo, S.H., 2017, Highly efficient adsorption of cationic dye by biochar produced with Korean cabbage waste, Bioresour. Technol., 224, 206-213.
[68] Jin, L., Zhao, X., Qian, X., and Dong, M., 2018, Nickel nanoparticles encapsulated in porous carbon and carbon nanotube hybrids from bimetallic metal-organic-frameworks for highly efficient adsorption of dyes, J. Colloid Interface Sci., 509, 245-253.

[69] Adekola, F.A., Ayodele, S.B., and Inyinbor, A.A., 2019, Activated biochar prepared from plantain peels: Characterization and Rhodamine B adsorption data set, Chem. Data Collect., 19, 100170.

[70] Wu, J., Yang, J., Huang, G., Xu, C., and Lin, B., 2020, Hydrothermal carbonization synthesis of cassava slag biochar with excellent adsorption performance for Rhodamine B, J. Cleaner Prod., 251, 119717.

[71] Esvandi, Z., Foroutan, R., Peighambardoust, S.J., Akbari, A., and Ramavandi, B., 2020, Uptake of anionic and cationic dyes from water using natural clay and clay/starch/$/ \mathrm{MnFe}_{2} \mathrm{O}_{4}$ magnetic nanocomposite, Surf. Interfaces, 21, 100754.

[72] Rahmani, M., Kaykhaii, M., and Sasani, M., 2018, Application of Taguchi L16 design method for comparative study of ability of $3 \mathrm{~A}$ zeolite in removal of Rhodamine B and Malachite green from environmental water samples, Spectrochim. Acta, Part A, 188, 164-169.

[73] Cheng, Z.L., Li, Y.X., and Liu, Z., 2017, Novel adsorption materials based on graphene oxide/Beta zeolite composite materials and their adsorption performance for rhodamine B, J. Alloys Compd., 708, 255-263.

[74] Tao, X., Wang, S., and Li, Z., 2020, Ultrasoundassisted bottom-up synthesis of Ni-graphene hybrid composites and their excellent Rhodamine B removal properties, J. Environ. Manage., 255, 109834.

[75] Damiyine, B., Guenbour, A., and Boussen, R., 2017, Rhodamine $\mathrm{B}$ adsorption on natural and modified Moroccan clay with cetyltrimethylammonium bromide: Kinetics, equilibrium and thermodynamics, J. Mater. Environ. Sci., 8 (3), 860-871.

[76] Thakur, A., and Kaur, H., 2017, Response surface optimization of Rhodamine B dye removal using 
paper industry waste as adsorbent, Int. J. Ind. Chem., 8 (2), 175-186.

[77] Cui, W., Kang, X., Zhang, X., and Cui, X., 2019, Gellike $\mathrm{ZnO} / \mathrm{Zr}-\mathrm{MOF}$ (bpy) nanocomposite for highly efficient adsorption of Rhodamine B dye from aqueous solution, J. Phys. Chem. Solids, 134, 165-175.

[78] Konicki, W., Siber, D., and Narkiewicz, U., 2017, Removal of Rhodamine $\mathrm{B}$ from aqueous solution by $\mathrm{ZnFe}_{2} \mathrm{O}_{4}$ nanocomposite with magnetic separation performance, Pol. J. Chem. Technol., 19 (4), 65-74.

[79] Singh, J., and Basu, S., 2020, Synthesis of mesoporous magnetic $\mathrm{Fe}_{2} \mathrm{O}_{3} / g-\mathrm{C}_{3} \mathrm{~N}_{4}$ monoliths for Rhodamine B removal, Microporous Mesoporous Mater., 303, 110299.

[80] Ren, Y.N., Xu, W., Zhou, L.X., and Zheng, Y.Q., 2017, Efficient tetracycline adsorption and photocatalytic degradation of rhodamine B by uranyl coordination polymer, J. Solid State Chem., 251, 105-112.

[81] Laysandra, L., Sari, M.W.M.K., Soetaredjo, F.E., Foe, K., Putro, J.N., Kurniawan, A., Ju, Y.H., and Ismadji, S., 2017, Adsorption and photocatalytic performance of bentonite-titanium dioxide composites for methylene blue and rhodamine B decoloration, Heliyon, 3 (12), e00488.

[82] Huang, H., Zhang, J., Jiang, L., and Zang, Z., 2017, Preparation of cubic $\mathrm{Cu}_{2} \mathrm{O}$ nanoparticles wrapped by reduced graphene oxide for the efficient removal of rhodamine B, J. Alloys Compd., 718, 112-115.

[83] Khan, M.A., Momina, Siddiqui, M.R., Otero, M., Alshareef, S.A., and Rafatullah, M., 2020, Removal of Rhodamine B from water using a solvent impregnated polymeric Dowex 5WX8 resin: Statistical optimization and batch adsorption studies, Polymers, 12 (2), 1-12.

[84] Kooh, M.R.R., Lim, L.B.L., Lim, L.H., and Dahri, M.K., 2016, Separation of toxic rhodamine B from aqueous solution using an efficient low-cost material, Azolla pinnata, by adsorption method, Environ. Monit. Assess., 188 (2), 1-15.

[85] Parthasarathy, P., and Narayanan, S.K., 2014, Determination of kinetic parameters of biomass samples using thermogravimetric analysis, Environ. Prog. Sustainable Energy, 33 (1), 256-266.

[86] Postai, D.L., Demarchi, C.A., Zanatta, F., Melo, D.C.C., and Rodrigues, C.A., 2016, Adsorption of Rhodamine $B$ and methylene blue dyes using waste of seeds of Aleurites Moluccana, a low cost adsorbent, Alexandria Eng. J., 55 (2), 1713-1723.

[87] Shouman, M.A., and Fathy, N.A., 2018, Microporous nanohybrids of carbon xerogels and multi-walled carbon nanotubes for removal of Rhodamine B dye, J. Water Process Eng., 23, 165-173.

[88] Bello, O.S., Adegoke, K.A., Sarumi, O.O., and Lameed, O.S., 2019, Functionalized locust bean pod (Parkia biglobosa) activated carbon for Rhodamine B dye removal, Heliyon, 5 (8), e02323.

[89] Wang, J., Gao, M., Shen, T., Yu, M., Xiang, Y., and Liu, J., 2019, Insights into the efficient adsorption of rhodamine $\mathrm{B}$ on tunable organo-vermiculites, $J$. Hazard. Mater., 366, 501-511.

[90] Zhu, Z., Xiang, M., Li, P., Shan, L., and Zhang, P., 2020, Surfactant-modified three-dimensional layered double hydroxide for the removal of methyl orange and Rhodamine B: Extended investigations in binary dye systems, J. Solid State Chem., 288, 121448.

[91] Geetha Malini, P.S., Durgadevi, P., Senthil Kumar, N., and Rani, S., 2020, Synthesis and characterisation of $\mathrm{CdO}$ nanoparticles: An efficient nanomaterial for the removal of Rhodamine $B$, Mater. Today: Proc., In Press, Corrected Proof.

[92] Saharan, P., Sharma, A.K., Kumar, V., and Kaushal, I., 2019, Multifunctional CNT supported metal doped $\mathrm{MnO}_{2}$ composite for adsorptive removal of anionic dye and thiourea sensing, Mater. Chem. Phys., 221, 239-249.

[93] Skarga-Bandurova, I., Krytska, Y., Shorokhov, M., Suvorin, O., Barbaruk, L., and Ozheredova, M., 2019, Towards development IoT-based water quality monitoring system, The $7^{\text {th }}$ International Conference on Future Internet of Things and Cloud Workshops (FiCloudW 2019), Institute of Electrical and Electronics Engineers Inc., 140-145. 